\title{
Women's Participation and Leadership in Lebanon, Jordan and Kurdistan Region of Iraq: Moving from individual to collective change
}

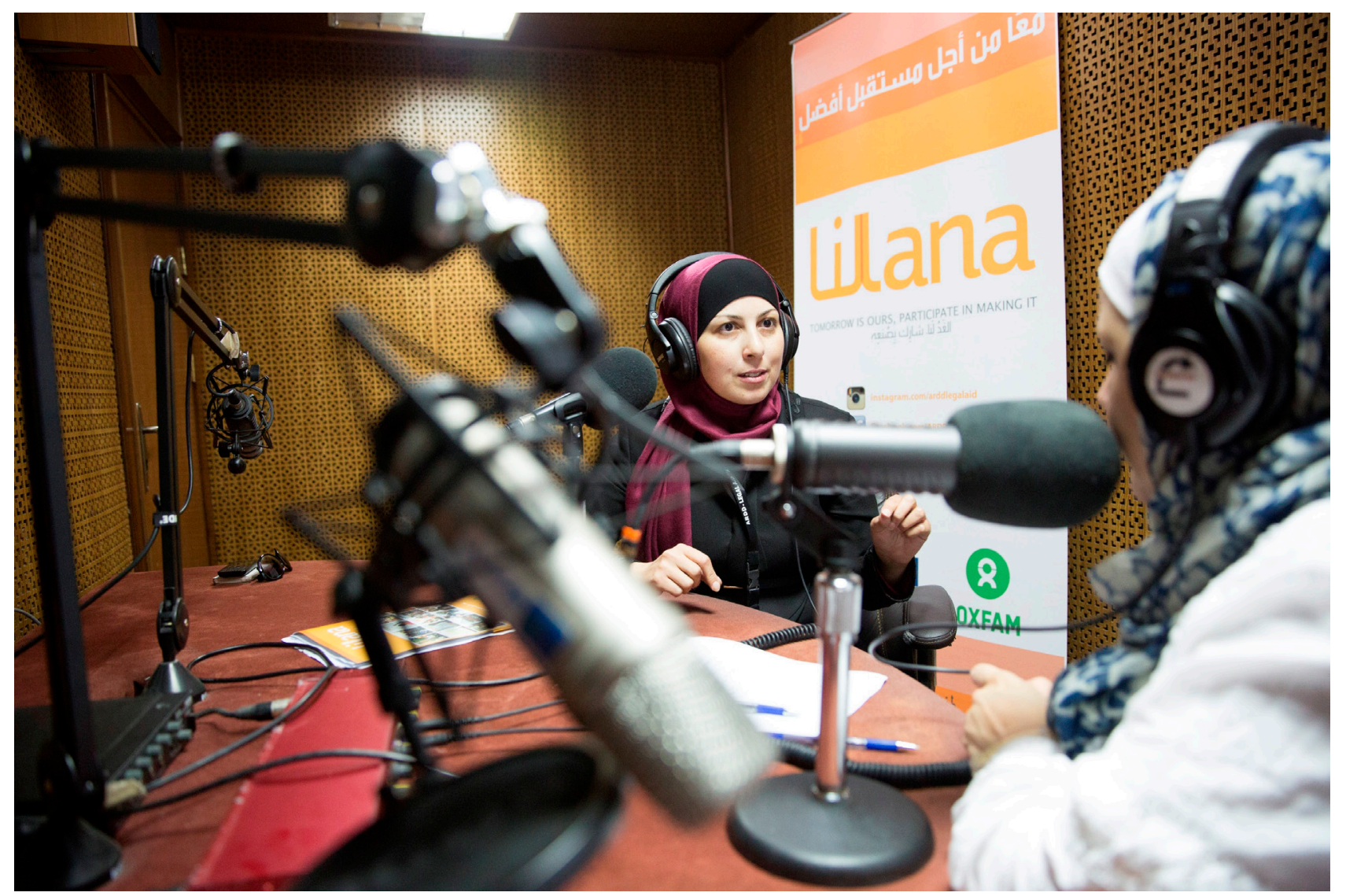

Lana Change Makers Luma Abdelfattah and Rawan Khreis are interviewed on Farah Al Nas Radio station. Photo credit: Mustapha Assi.

April 2016

Authors: Dina Kiwan, May Farah, Rawan Annan and Heather Jaber, American University of Beirut, Beirut, Lebanon 
This research report was written to share research results, to contribute to public debate and to invite feedback on development and humanitarian policy and practice. It does not necessarily reflect Oxfam or AUB policy positions. The views expressed are those of the author and not necessarily those of Oxfam or AUB.

For more information, or to comment on this document, email Dr Abigael Badoumas at ABaldoumas@oxfam.org.uk

\section{Acknowledgements}

This report is the outcome of a seven-month research project collecting data on women's participation and leadership across Lebanon, Jordan and Kurdistan Region of Iraq (KRI), written by the research team in the Department of Sociology, Anthropology and Media Studies at the American University of Beirut (AUB), and led by the Principal Investigator, Professor Dina Kiwan.

Other members of the research team who are contributing authors to this report are Co-Investigator, Professor May Farah, and researchers Ms Rawan Annan and Ms Heather Jaber. Special thanks goes to Mr Chafic Najem, who was part of the research team during the data-collection phase of the project, with special responsibility for male focus groups across the three countries. We are also indebted to Ms Khanzad Abed Ahmad for her invaluable knowledge and experience in Erbil, and her support in the data collection from Erbil.

The research team was supported by an advisory board of academics at AUB and local practitioners who played an important role advising on data collection, analysis and write-up of the project. Members included: Professor Jocelyn Dejong (Faculty of Health Sciences), Professor Charlotte Karam (Business), Mr Fateh Azzam (Director of Asfari Institute of Civil Society and Citizenship), Dr Rania Masri (Associate Director, Asfari Institute of Civil Society and Citizenship) and Ms Ghida Anani, Director of ABAAD (Resource Centre for Gender Equality), Lebanon. AUB's Institutional Research Board provided support for research ethics requirements for the project, and AUB's Office of Grants and Contracts was responsible for managing the financial aspects.

Finally, we would like to thank Oxfam for the continued support throughout the research process as well as the logistical support during research team visits to Jordan and KRI, with special thanks to Dr Abigael Baldoumas for leading this. 


\section{Table of contents}

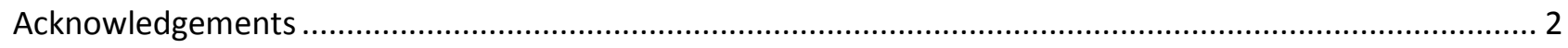

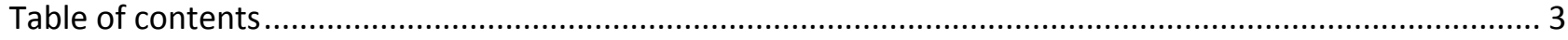

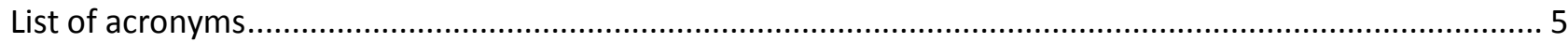

UN Agencies and World Agencies ................................................................................. 5

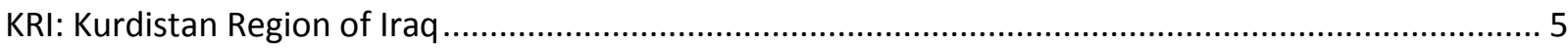

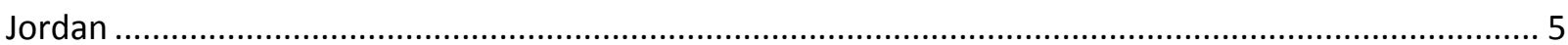

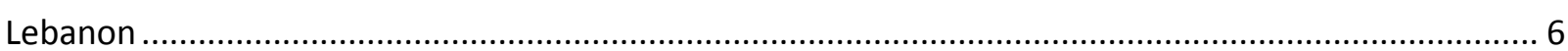

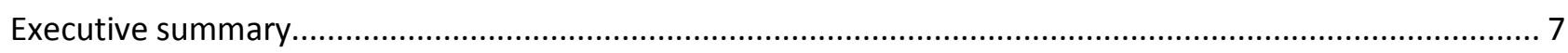

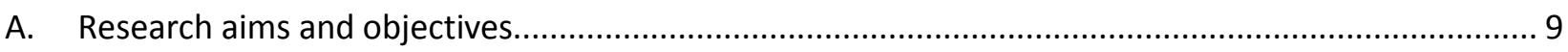

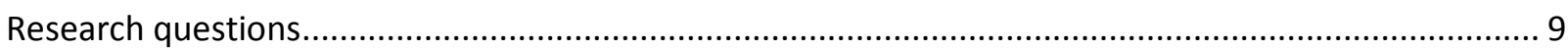

B. Brief historical and political contextualization for the three locations .......................................... 10

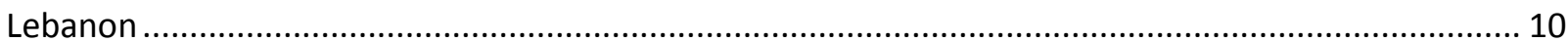

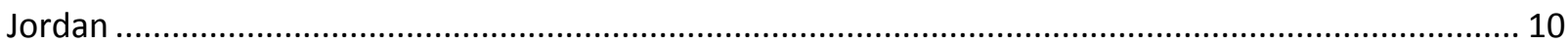

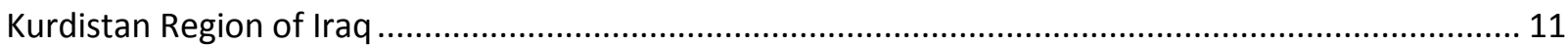

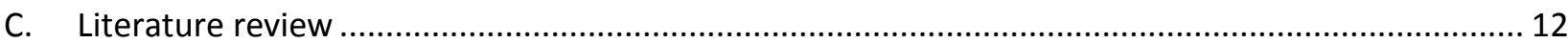

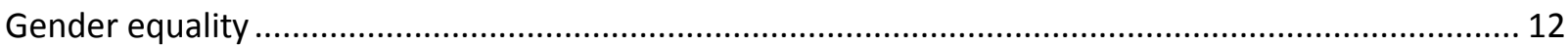

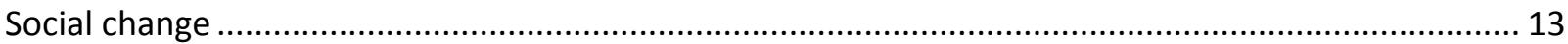

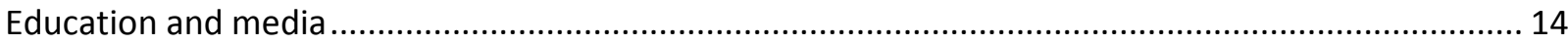

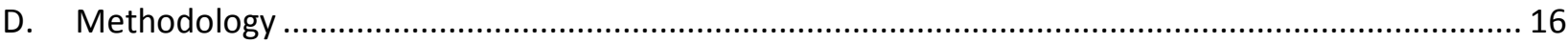

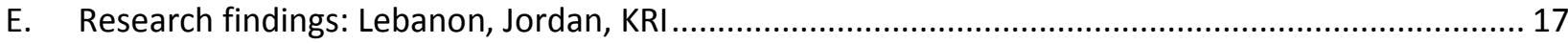

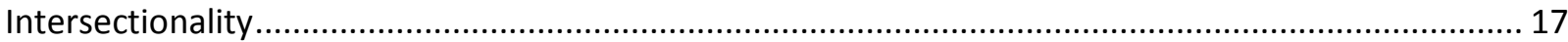

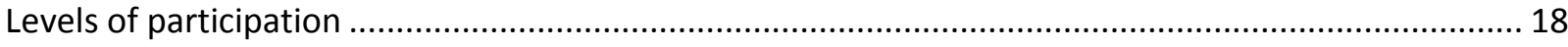

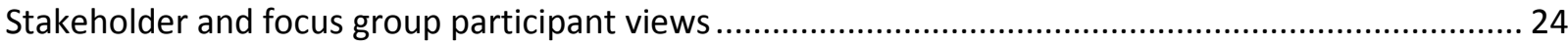

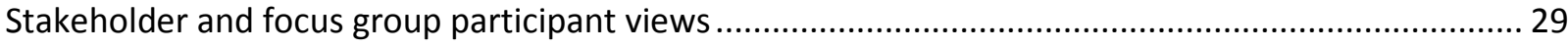

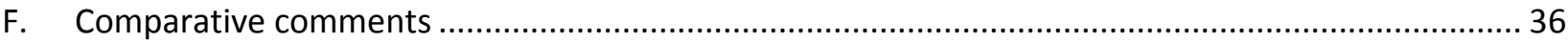

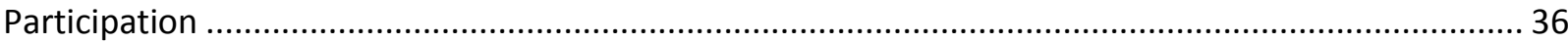

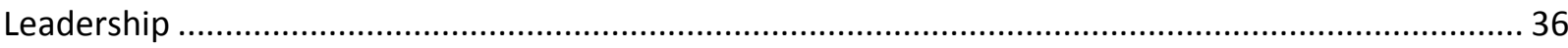

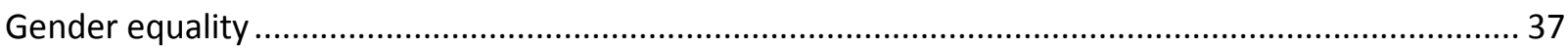

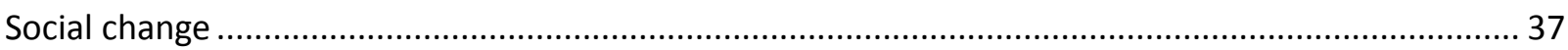

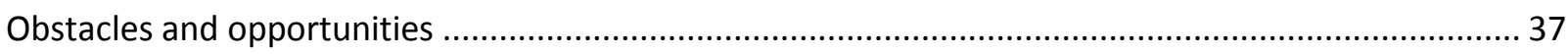

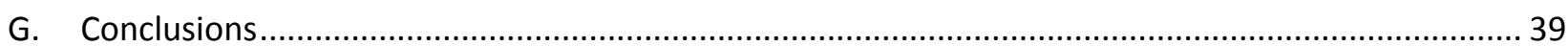

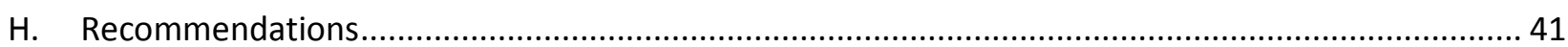

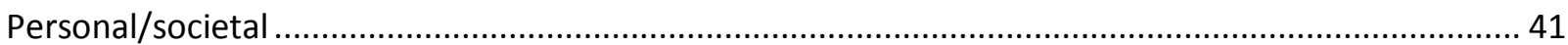

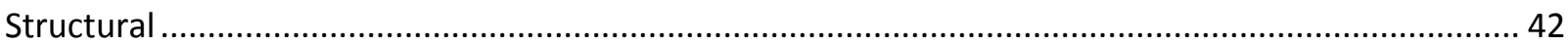

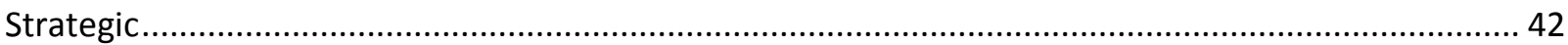




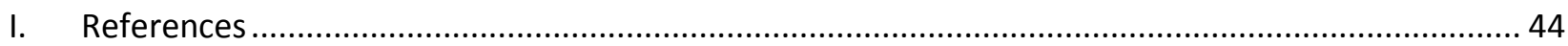

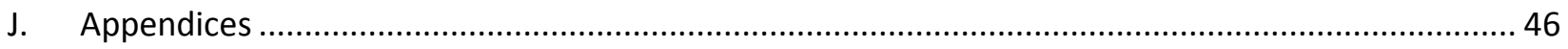

Appendix 1: Tables of comparative gender statistics by country ............................................... 46

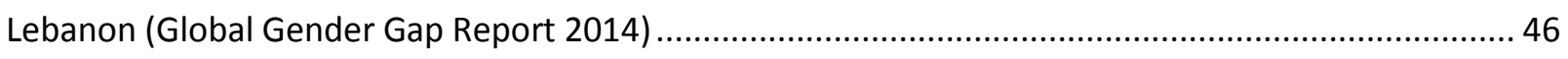

Jordan (Global Gender Gap Report 2014) .........................................................................47

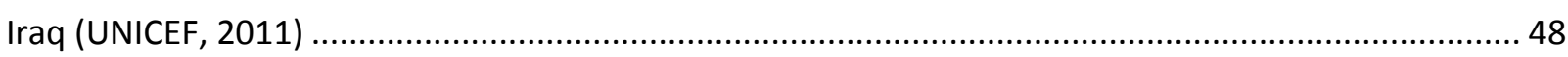

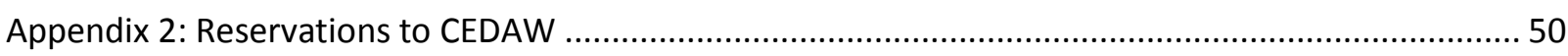

Appendix 3: List of Stakeholders and focus groups by country/region........................................... 51

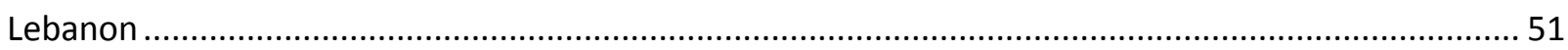

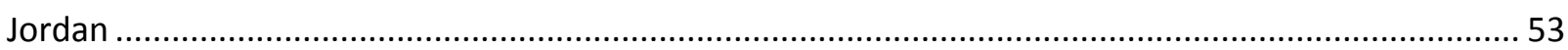

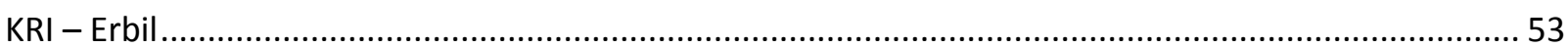

Table showing breakdown by gender at each of the sites of data collection across the three countries

Appendix 4: Schedule of questions for stakeholders .......................................................... 54

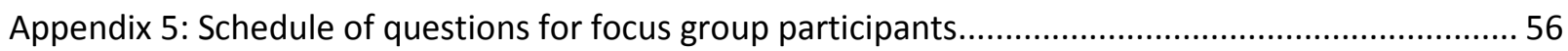

Conceptual understandings of women's 'participation' and 'leadership' .......................................56

Appendix 6: Written consent form Written Consent Form for Stakeholder interviews .....................57

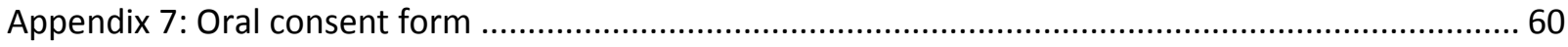

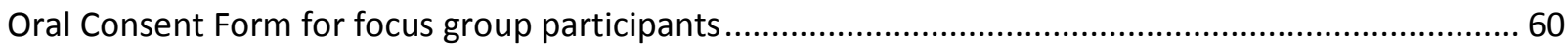

Appendix 8: Tables of perceptions of obstacles to women's participation and leadership .................63

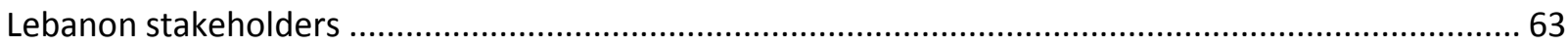

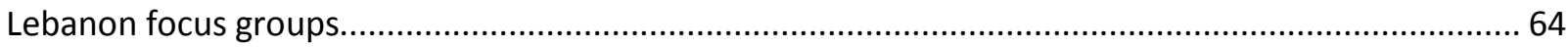

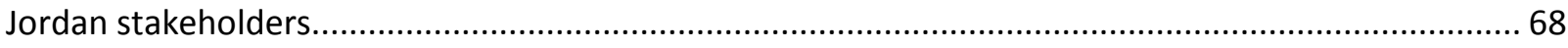

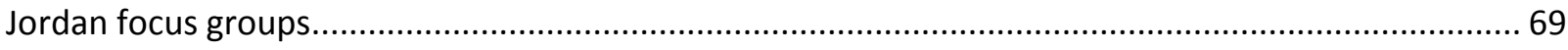

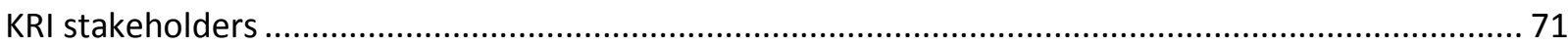

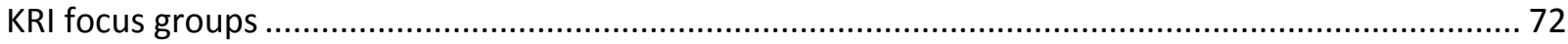




\section{List of acronyms}

CEDAW: Convention on Elimination of All Forms of Discrimination against Women CSO: Civil society organization FGM: female genital mutilation GBV: Gender-based violence ICT: Internet and communications technology

ISIS: Islamic State in Iraq and Syria

KRG: Kurdistan Regional Government

LGBTQI: Lesbian, gay, bisexual, transgender, queer, questioning and intersex MP: Member of Parliament

NGO: Non-governmental organization

\section{UN Agencies and World Agencies}

HRW: Human Rights Watch

ESCWA: Economic and Social Commission for Western Asia

UN: United Nations

UNDP: United Nations Development Programme

UNESCO: United Nations Educational, Scientific, and Cultural Organization UNFPA: United Nations Population Fund UNHCR: United Nations High Commissioner for Refugees

UNICEF: United Nations Children's Fund

UNRWA: United Nations Relief and Works Agency

USAID: United States Agency for International Development

\section{KRI: Kurdistan Region of Iraq}

PAO: Public Aid Organization

WEO: Women's Empowerment Organization

\section{Jordan}

JOHUD: The Jordanian Hashemite Fund for Human Development

JWU: Jordanian Women's Union

SIGI: Sisterhood Is Global Institute

QRF: Queen Rania Foundation

WSC: Center for Women's Studies (WSC) 


\section{Lebanon}

ABAAD: Resource Centre for Gender Equality

AFE: Arab Foundation for Freedoms and Equality

AUB: American University of Beirut

CFUWI: The National Committee for the Follow up of Women's Issues

CLW: College Louise Wegmann

CRDTA: Collective for Research and Training on Development - Action

DPNA: Development for People and Nature Association

GRSC: Gender and Sexuality Resource Center

ISF: Internal Security Forces (Lebanese Police)

IWSAW: Institute for Women's Studies in the Arab World

LECORVAW: The Lebanese Council to Resist Violence Against Women

LLWB: League of Lebanese Women in Business

LU: Lebanese University

MEU: Middle East University

NCLW: National Commission for Lebanese Women

PAWL: Palestinian Arab Women's League

SHIELD: Social, Humanitarian, Economical Intervention for Local Development

WIF: Women in Front

YWCA: Young Women's Christian Association 


\section{Executive summary}

This is the report of the findings of a seven-month qualitative study commissioned by Oxfam with the overall aim to explore the dynamics that lead from individual change in perceptions and attitudes on gender equality and women's participation and leadership in Lebanon, Jordan and Kurdistan Region of Iraq (KRI). The two specific objectives of the research project were: i) to conduct a comparative assessment of the role that customary institutions play in maintaining gender inequality in Lebanon, Jordan and KRI; and ii) to analyse the chain of changes in perceptions and attitudes on gender equality from the individual sphere to the social and political spheres, and from local to national level. The report consists of a preliminary and condensed literature review focused on the themes of gender equality, social change and the potential role of education and media, entailing theoretical and empirically contextualized findings; this is followed by the qualitative empirical research across the three country sites, entailing interviews with stakeholders and focus group discussions with men and women from a diverse range of backgrounds.

The first objective was approached in terms of three research sub-questions examining: i) the nature of women's participation and how this varies in relation to age, socio-economic status, religion, legal status etc.; ii) perceived obstacles to participation, and iii) key stakeholders' views on gender equality and women's participation. Based on interviews with stakeholders and male and female focus group participants across the three countries, key findings are that women's participation in society is widely recognized to be important in both the public and private spheres. It was recognized that participation varies significantly according to women's age, marital status, religion, socio-economic background and legal status, illustrating the importance of taking an intersectionally nuanced approach in understanding and promoting women's participation and gender equality.

Across all three country sites, economic participation was perceived to be particularly important; however, rationales for women's participation were broadly framed in instrumental terms rather than in terms of gender equality and women's rights. While women's participation in education has been seen to have risen over the last decade, the significant gap between education and employment remains, and in addition, levels of participation vary considerably depending on age, marital status, socio-economic status and legal status. There was relatively less consensus on women's leadership, with men in Jordan and South Lebanon in particular expressing views of women's 'emotional nature' limiting their leadership capacities. Dissatisfaction is also expressed regarding low levels of women's political participation, especially in Lebanon, but also in Jordan and KRI where, even though quotas are in place, there is a perception that women do not actually hold autonomous decision making capacity or promote gender equality per se.

These findings illustrate highly gendered constructions of male and female roles in society, based on essentialized understandings of what it means to be a 'man' or a 'woman'. While gender equality was agreed to be 'a good thing' in the abstract, there were mixed views on the forms this would take in practice. In addition, distinctions were made between equality and justice, constructed in terms of what was perceived to be 'gender-appropriate'. Men tended to express the view that gender equality exists in society, which is in stark contrast to empirical data that ranks Jordan and Lebanon at 134 and 135 respectively out of 142 countries in the 2014 Global Gender Gap Report. Some men expressed the view that equality did not necessarily mean equal opportunities or equal treatment per se, but rather drew on a discourse of what is perceived to be just and gender-appropriate - based on biologically essentialized constructions of male- and female-ness. Paradoxically, some men expressed the idea that gender equality was a Western concept not applicable to their local context, and a cause of conflict between men and women.

While religion was referred to in discussions, it was not seen as a significant obstacle to gender equality; rather the challenge is how discourses of religious interpretations are used to legitimize patriarchal cultural practices. Socialization into different gendered roles was perceived to be an important obstacle to gender equality. Stakeholders tended to focus on structural and strategic obstacles to gender equality, whereas men and women in the focus groups emphasized personal-level and societal factors. This might indicate a gap in stakeholders' understandings of obstacles facing men and women at the level of individual, family 
and community relationships on the one hand, and on the other, a lack of knowledge among focus group participants of the institutional and structural obstacles to women's participation and leadership in society.

The second objective - focusing on the chain of changes in perceptions and attitudes on gender equality from the individual to societal sphere, and from local to national level - was approached in terms of eight research sub-questions. These were: i) women's and men's perceptions of current levels of participation (and how this varies in relation to age, socio-economic class, marital status, religion, legal status, etc.); ii) what influences views and how can these be changed?; iii) how can individual change lead to societal change, and how can change at local level lead to national-level change; iv) what are the existing opportunities; v) how does change happen?; vi) what strategies have worked and why?; vii) other initiatives or lessons learned; and viii) recommendations for action. Given the scope and scale of the research, the findings provide some context-specific data on this issue, but are limited in terms of fully elucidating a theory of social change, and further research will be necessary to explore this in more detail.

Stakeholders, and women and some men focus group participants in all three country sites expressed the belief that bringing about positive change to promote gender equality and women's participation and leadership is important in their communities, and that some modest change had occurred over the last decade. In terms of changing individual attitudes and beliefs, participants in all three country sites emphasized the importance of an integrated approach combining structural, legal change as well as grassroots change within families and local communities. A clear difference emerged between stakeholder and focus group perceptions, with stakeholders more likely to identify structural and strategic factors as obstacles to gender equality (e.g. laws or institutional access, childcare provision) compared to focus group participants' relative emphasis on personal and societal factors (e.g. the perceptions of husbands, notions of shame or honour, socialization into highly gendered roles, essentialized biological notions of masculinity and femininity, perceptions of physical and sexual vulnerability, and fear of violence). Men tended to take a more functionalist approach, proposing relatively minor changes and preserving the status quo, and supporting differentiated gender roles and differential gender socialization. The majority of views saw social change as something gradual and taking time. In Jordan and KRI, where gender quotas have been institutionalized, participants emphasized the importance of changing individuals' perceptions.

Education, media and social media were frequently mentioned across all three countries as providing opportunities or acting as facilitators for social change. We propose that this supports a model of social change where education and media - while they can act to represent and transmit the state's aims and values - can also be conceptualized to operate as a dynamic 'meso-level' domain for social transformation. In the case of education, teachers and the pedagogic relationship play a vital part, along with the family. As such, education plays a critically important role as a link between the micro-level of personal attitudes and the macro-level of social change - facilitating the chain of changes from the personal to the societal level. 


\section{A. Research aims and objectives}

This is the report of a qualitative study commissioned by Oxfam with the following research aims and objectives:

Aims: The research will explore the dynamics that lead from individual change in perceptions and attitudes on gender equality to wider social and political change.

The specific objectives are as follows:

1. To conduct a comparative assessment of the role customary institutions play in maintaining gender inequality in Lebanon, Jordan and KRI.

2. To analyse the chain of changes in perceptions and attitudes on gender equality from the individual sphere to the social and political spheres, and from local to national level.

Below are the research questions relating to the research objectives.

\section{Research questions}

Objective 1: A comparative assessment of the role customary institutions play in maintaining gender inequality and limiting women's political participation in Jordan, Lebanon and KRI

\begin{tabular}{|c|c|}
\hline 1 & $\begin{array}{l}\text { How do women participate in social and political life? How does their participation vary across } \\
\text { religious, tribal, political, socio-economic and national lines? }\end{array}$ \\
\hline 2 & $\begin{array}{l}\text { What obstacles (personal, social, cultural, economic, legal, institutional, security, political, tribal } \\
\text { and religious) hinder gender equality and women's political participation? }\end{array}$ \\
\hline 3 & $\begin{array}{l}\text { Who are the stakeholders (formal and informal) involved in political participation? What are their } \\
\text { positions on gender equality and women's political participation? }\end{array}$ \\
\hline \multicolumn{2}{|r|}{$\begin{array}{l}\text { Objective 2: Analysis of chain of changes from individual to social and political, and from local to } \\
\text { national level }\end{array}$} \\
\hline 1 & $\begin{array}{l}\text { How do women and men view the current level of women's political participation and gender } \\
\text { equality? How do these views vary across religious, tribal, political, socio-economic and national } \\
\text { lines? }\end{array}$ \\
\hline 2 & $\begin{array}{l}\text { What influences women's and men's views and attitudes on gender equality? How can these } \\
\text { views be changed? (What arguments, evidence and strategies can be deployed?) }\end{array}$ \\
\hline 3 & $\begin{array}{l}\text { How can the individual change in perceptions and attitudes on gender equality be transformed } \\
\text { into social and political change and move from the local to the national level? }\end{array}$ \\
\hline 4 & $\begin{array}{l}\text { What are the existing national and regional opportunities (social, legal, government initiatives, } \\
\text { funding and alliances) for furthering gender justice and women's political participation? }\end{array}$ \\
\hline 5 & How does this change happen (step-by-step process/theory of change)? \\
\hline 6 & $\begin{array}{l}\text { What strategies have worked to further gender equality and women's political participation? } \\
\text { Why? }\end{array}$ \\
\hline 7 & $\begin{array}{l}\text { Are there other initiatives working on transforming personal change to political and social } \\
\text { change? What factors have contributed to their success/failure? What are the key lessons } \\
\text { learned? }\end{array}$ \\
\hline 8 & What are the recommendations for action to ensure this shift? \\
\hline
\end{tabular}




\section{B. Brief historical and political contextualization for the three locations}

\section{Lebanon}

Lebanon, which achieved independence in 1943, now has a population of 4.7 million and can be characterized by its religious diversity, which is also a defining feature in relation to its politics. There are 18 recognized religious sects, and in terms of political representation this is organized in relation to the three major sects of Maronite Christians, Sunni Muslims and Shiite Muslims, based on a census taken in $1932 .{ }^{1}$ As a consequence, there are at least 15 personal statute codes governing matters of personal status law, including, for example, marriage, divorce, and inheritance. This fragile power-sharing arrangement has come under strain from internal conflict (16 years of civil war), regional political alliances, the influx of almost half a million Palestinian refugees in Lebanon ${ }^{2}$ (with about half of this population in refugee camps dating back to 1948 and the creation of the state of (srael), and most recently the influx of over 1.5 million Syrian and Syrian Palestinian refugees as a result of the ongoing Syrian conflict. ${ }^{3}$ Of the registered refugee population, 78 percent are women and children. ${ }^{4}$

In Lebanon, women achieved the right to vote in 1953 after the country gained independence from France. However, this was not as a result of campaigning for women's rights; rather it was considered to be in the state's broader political interests. Very few women have ever served in Parliament since suffrage; this is attributed to the patriarchal culture and a political culture which has been dominated by a small number of elite families since the 1950s. As also referred to in the following literature review section, this lack of women's representation in formal politics remains unchanged.

\section{Jordan}

Jordan became an independent sovereign state in 1946, and is a constitutional monarchy, although the King holds significant executive and legislative powers, acting as Head of State and Commander-in-Chief, and is responsible for appointing the executive branch of Prime Minister, Cabinet of Jordan and regional governors. The Parliament consists of the House of Representatives (democratically elected from 12 constituencies) and the Senate, which is directly appointed by the King. A new draft of the election law was approved in September 2015, replacing a one-person, one-vote system with a multi-vote for tickets at constituency level. The number of House of Representatives seats has been reduced from 150 to 130 . There is a quota of 15 seats for women in the House of Representatives, as well as seats allocated for Jordanian Christians, Circassians and Chechens. Political parties typically hold fewer than 20 percent of the seats, with the rest held by independent politicians. Jordan has both Sharia and civil courts, where civil courts deal with civil and criminal cases, and the Sharia courts deal with personal status cases for marriage, divorce and inheritance. Demographically, Jordan has a population of around eight million with influxes of Palestinian refugees since 1948. According to United Nations Relief and Works Agency (UNRWA), most of its two million registered Palestinian refugees are now Jordanian citizens, with Jordan hosting the largest number of Palestinian refugees of all the UNRWA fields of operation. There are significant numbers of Iraqi refugees (approximately 58,000), migrant workers and most recently Syrian and Syrian-Palestinian refugees in Jordan, estimated to reach close to one million by December $2015 .{ }^{5}$ There are currently 628,000 registered Syrian refugees, and around 10,000 recorded Palestinian refugees, although it is claimed by various sources that there are close to 1.5 million Syrians in Jordan, including those fleeing the crisis but also those who were working as migrant labourers in Jordan before the crisis began.

\footnotetext{
${ }^{1}$ Faour, 2007.

2 UNRWA, 2013.

${ }^{3}$ UNHCR, 2014.

${ }^{4}$ UNHCR, 2014.

${ }^{5}$ UNHCR, 2015.
} 
Historically, the state paid relatively little attention to women's rights. Initially, royal princesses supported campaigns for children and poor women, but by 1954, middle-class women mobilized to campaign against female illiteracy and on other citizenship rights, forming the Arab Women's Federation. Their campaign for suffrage continued throughout the 1950s and 1960s, until the law was amended in 1974 giving all women the right to vote.

\section{Kurdistan Region of Iraq}

Iraq gained its independence in 1932, although the UK maintained a military presence until 1954. The Hashemite monarchy was overthrown in 1958, followed by another coup in 1963. In 1968, the Ba'ath party took over, with Saddam Hussein taking the presidency in 1979. The Iran-Iraq war from 1980-88 resulted in an estimated death toll of over one million people, and the Iraqi Kurds were targeted leading to the deaths of up to 100,000 people. Iraq's recent history is characterized by significant conflict and violence with two Gulf wars, US-led military intervention, and sectarian Sunni-Shia violence. Following US withdrawal in 2011, Iraq has suffered from extreme political violence, with ISIS (Islamic State in Iraq and Syria) controlling large parts of Iraqi territory.

Historically, women and girls in Iraq have enjoyed relatively more rights than women in other countries across the Arab world. ${ }^{6}$ The 1970 Iraqi Provisional Constitution guaranteed equal rights to women, including the right to vote, to education, to run for political office and also to own property, and in 1986 Iraq was one of the first countries to ratify the Convention on Elimination of All Forms of Discrimination against Women (CEDAW), although there were reservations made on the grounds of aligning the convention with Islamic law. ${ }^{7}$ Women played a significant economic and political role in Iraq until the 1991 Gulf War, but since then, women's civil, economic and political rights have suffered. However, there have been some positive developments relating to personal status laws regarding divorce and child custody.

Kurdistan Region of Iraq (KRI) has semi-autonomy, with Erbil as its capital. There is a history with regards to Kurdish attempts to establish autonomy, which was only formally ratified with the new Constitution of Iraq in 2005. An autonomy agreement in 1970 failed to hold, resulting in further conflict between Kurds and the Arab-dominated Iraqi government. The Iran-Iraq war (1980-88) and the Anfal genocide in 1988 further decimated the Kurdish population. In 1991 there was a Kurdish uprising against Saddam Hussein, which eventually led to the basis for Kurdish de-facto self-rule and the return of Kurdish refugees to the north, with the ousting of Iraqi forces in October 1991. Kurdish political movements established the semiautonomous Kurdish Regional Government (KRG) in 1992. With the fall of Saddam Hussein in 2003, the subsequent political changes led to a new Iraqi constitution in 2005 , with Iraq defined as a federal state consisting of Regions and Governorates. The KRG has a Parliament elected by popular vote held every four years. There is a quota system whereby 25 percent of seats in Parliament are reserved for women. $\mathrm{KRI}$ is considered a federal entity of Iraq, with the new Iraqi constitution establishing Kurdish and Arabic as Iraq's joint official languages.

Like Lebanon and Jordan, Iraq and KRI have a patriarchal society restricting women's political and other forms of participation in the public sphere, as will be highlighted in the following section. In addition, both Jordan and KRI can be characterized as having tribal communities, also reinforcing patriarchal practices.

\footnotetext{
${ }^{6}$ HRW, 2003.

${ }^{7}$ HRW, 2003.
} 


\section{Literature review}

This section aims first to highlight key conceptual ideas, and compiles some pertinent empirical data on gender equality measures in the three countries. The second sub-section, on social change, considers different ways of understanding social change as a phenomenon in general, and then explores social change more specifically in relation to gender equality and women's participation and leadership in society. The third sub-section identifies education and media as key domains for bringing about change in knowledge and attitudes to gender equality, thereby offering potential for social change. These domains can be conceptualized as the 'bridge' between change at the personal level and wider societal change. The aim of the literature review is to provide a wider theoretical and empirical context in which to understand the research findings.

\section{Gender equality}

There are different theories of gender equality, which can broadly be categorized into three main approaches. ${ }^{8}$ Functionalist approaches perceive gender differences as contributing to social stability and cohesion, and that there is an implied 'naturalness' or biological basis to this form of societal organization. Feminist approaches typically attribute gender differences to differential socialization into learned gender roles, which are socially constructed. Thirdly, more radical approaches propose that neither gender nor sex have a biological basis, but both are entirely social constructed ('postmodern feminism' or 'queer theory'). The concept of gender equality is a contested one, with contemporary Western conceptions inherently linked to notions of democracy and agency in both the public and private spheres. ${ }^{9}$ It is important to contextualize notions of equality within the intellectual history and socio-politics of the country or region, in order to understand local perceptions of the concept. In non-Western contexts, gender equality is often associated with modernization and human development. ${ }^{10}$

While gender equality and women's participation and leadership in the public sphere is important, it is necessary not only to ascertain the quality of that participation and leadership, but also to take account of women's lived experiences in both the public and private spheres in a historical and socio-political perspective. This more qualitative data, based on interviews with stakeholders and women's and men's focus groups, is reported in the section on findings, to complement the quantitative data on gender equality collected through international initiatives as reported here. Gender equality is the third UN Millenium Development Goal, and is a global priority of a number of international organizations and platforms, including UNESCO, the Beijing+20 review and the Post-2015 Development Agenda, which all provide an opportunity to place gender equality and women's empowerment at the centre of the global agenda.

According to the Global Gender Gap Report 2014, Lebanon is ranked 135 out of 142 countries, and Jordan is ranked at 134. Iraq is not ranked in this report. It should also be noted that Erbil, as well as the Kurdistan Region as a whole, is perceived as politically and culturally distinct from other areas of Iraq, although sharing commonalities in terms of traditional family and tribal patriarchal practices. For comparative gender statistics on economic and educational participation, leadership and for other measures of gender equality by each country, please see Appendix 1.

In terms of structural legal barriers to gender equality it is also relevant to look at reservations to CEDAW made by the three countries. In summary, these relate to provisions of equality pertaining to marriage, divorce and nationality. In Iraq and Jordan, personal status laws are governed by the Sharia, while in Lebanon they are devolved to the 18 sects: in all three countries, women have more circumscribed rights in relation to applying for divorce, cannot be granted legal guardianship over their children (with the

\footnotetext{
${ }^{8}$ Giddens and Sutton, 2014.

${ }^{9}$ Sieder and McNeish, 2013.

${ }^{10}$ Basu, 1995.
} 
exception of Armenian Christians in Lebanon) and do not have legal protection against spousal rape. In addition, women are only legally entitled to half the share of men's inheritance, with the common practice that women do not claim their reduced inheritance in Jordan. Fuller details are in Appendix 2.

\section{Social change}

Fundamentally, any effective initiative working on promoting gender equality and women's participation and leadership must necessarily be underpinned by a theory of social change. Social change, like gender equality, is a contested concept with many different definitions, phenomena, levels of analysis, and contexts. Functionalist approaches ${ }^{11}$ see change as necessary and desirable as long as it is gradual over time, in order to largely preserve the status quo. In contrast, conflict theory (e.g. Marxism) conceives of social change arising from social inequality, and holds that protest is desirable and necessary in order to achieve social change.

Social change can be conceived of in terms of both the notion of structure - including social, legal and political institutions, and also ways of living and thinking as reflected in language, beliefs, values, customs and lived practices. As such, social change deals with both the macro and micro levels, in what is also often referred to as 'top-down' and 'bottom-up' approaches respectively. Social change is about social relationships between individuals and groups within society, and so necessarily invokes power relations. Foucault's work on power as not necessarily something that individuals possess - but rather as something that is pervasive, diffused, relational and fluctuating through society - makes a conceptual shift away from the concepts of agency and structure and instead refers to power/knowledge, which says that societies' regimes of truth make certain discourses acceptable and certain institutions and people authorities on 'what counts as true'. ${ }^{12}$ This conception of power is more compatible with ideas of social change that recognize that individuals, including marginalized people, can contribute to bringing about social change through thinking in new ways and 'creating' new knowledges or discourses within society. Education and the media are important domains for this construction of alternative 'knowledges'. Such a conception of power also recognizes that what are assumed to be powerful institutions are not static, but are themselves subject to change through interaction with the changing social and political context within which they are embedded: 'Discourse transmits and produces power; it reinforces it, but also undermines and exposes it, renders it fragile and makes it possible to thwart. ${ }^{13}$

Oxfam's 'LANA' project aims to promote gender equality and women's political participation by changing men's and women's attitudes with regards to gender roles and understandings of citizenship. ${ }^{14}$ It is based on the 'We Can' ${ }^{15}$ approach, whereby recruited individuals act as 'changemakers' in their communities. During the first phase of the LANA initiative, these changemakers will raise awareness of gender roles, the idea being that personal change can lead to large-scale social transformation. The emphasis is thus on micro-level change, while acknowledging macro-level constraints such as religious discourses and practices, family and tribal constructions of gender roles, and political and legal institutions. It is anticipated that further work may aim to consolidate and build on the first phase. ${ }^{16}$

It is important to note that the idea of social change with respect to gender equality and women's participation and leadership in society is premised on a particular understanding of liberal-democratic

\footnotetext{
${ }^{11}$ For example, Talcott Parsons, 1966.

${ }^{12}$ Rabinow, 1991.

${ }^{13}$ Foucault, 1998.

${ }^{14}$ Oxfam, 2014a.

${ }^{15}$ 'We Can' has been Oxfam GB's largest-scale intervention on violence against women (VAW). Launched in late 2004, with the goal of 'reducing the social acceptance of violence against women', the campaign started in six South Asian countries - Afghanistan, Bangladesh, India, Nepal, Pakistan and Sri Lanka - but has since spread to others.

${ }^{16}$ Oxfam, 2014b.
} 
citizenship as a social contract between equal citizens and a functioning democratic state. It has been argued that in the Arab region, and specifically in the three countries of Lebanon, Jordan and Iraq, neither men nor women are citizens first and foremost; they are firstly members of families, tribes or sects. In addition, many living in these countries are not legally citizens at all - being refugees or migrant workers, with significantly curtailed civil, political and social rights. Conceptions of participation and leadership also reflect 'participatory' conceptions of citizenship, ${ }^{17}$ whereby citizens (as well as non-citizens), based on human rights discourses and international laws, have rights and responsibilities and play an active role in their societies, which are accountable and democratic.

In 'translating' such concepts to the Arab world, it is important to recognize that the intellectual history of these concepts has developed in a European context. It is therefore important to think through and articulate what gender equality and women's leadership and participation means in the Arab region, which not only has different intellectual traditions, but different religious discourses and political legacies as a result of the postcolonial context, Pan-Arabism, regional politics, conflict and refugees, and migrant workers. Most recently, the uprisings and protests across the Arab world illustrate more individualistic calls for citizenship rights and social change, essentially calling for a new social contract. This is currently evident in the youth-led 'trash protests' in Lebanon, which are calling for basic human rights, social service provision and government accountability. Women are playing a leading role in these movements, which provide a potential space for social change in relation to gender equality and women's participation and leadership.

With regards to the LANA project - which broadly subscribes to a functionalist rather than a conflict model of social change - it is important to recognize that while there is a legacy of activism in the countries, this sense of agency that is enabled by the notion of a social contract, whereby the 'citizen' demands their rights from the 'state' with the expectation of change and success, may be less evident, especially among the more marginalized communities (e.g. by social class). This supports the idea of the need for education and awareness-raising around human rights, and in particular citizen rights. Looking at the experiences of the Arab uprisings - following a more conflict-driven model of social change - the notion of basic dignity has been a powerful mobilizer of agency, even, and perhaps especially, among the most marginalized people. It should be noted, however, that these are tentative observations, given that the scope and scale of the study was limited in fully addressing objective 2 , relating to analysing the chain of social change. This is further discussed in the section on methodology below.

\section{Education and media}

Educational institutions, educational policy, pedagogy and school curricula are key areas through which the state aims to propagate its objectives, and there is a wealth of literature on nation-building and citizenship policies through education. ${ }^{18}$ Yet it is important to recognize that these are areas of contestation, and provide opportunities for transformation and social change. When thinking about the role of education in social change, education can be conceptualized as the link between individual personal change and largescale societal change - the link between the 'micro' and 'macro' levels. Instead of viewing education as a restrictive form of 'governmentality' ${ }^{19}$ of the state, the dynamic nature of education should be recognized with its interactions between different participants (teachers, parents, local community, students). This understanding of education is underpinned by a Foucauldian concept of power, where power is better understood in terms of fluid power relations between people or groups, rather than as a static conception of certain institutions or people 'possessing' power and the marginalized lacking power.

As such, education provides a critically important opportunity for the promotion of gender equality and social change. It is therefore pertinent to look at UNESCO's work on gender equality, given its remit and

\footnotetext{
17 Kiwan, 2008.

${ }^{18}$ Kiwan, 2008; Kiwan, 2013.

${ }^{19}$ Pykett, 2010.
} 
focus on education. Gender equality is one of UNESCO's two global priorities (along with global education), and is envisioned not only in terms of rights but also as a prerequisite for sustainable, peaceful societies. It has produced a Gender Equality Action Plan for 2014-2021. One of its focus areas entails promoting positive gender images and countering stereotypical gender representations in school curricula and textbooks, pedagogical practice and teacher-training, as well as in the media. It also focuses on women's leadership to promote positive role models and decision making in all domains. Global citizenship education ${ }^{20}$ also prioritizes gender equality through transformative pedagogy. In addition, UNESCO has most recently published an international guide on gender equality in teacher education, ${ }^{21}$ with an annex on gender equality in teacher education in the Arab world also being published. ${ }^{22}$

While access to primary and secondary education in the Arab world has substantively increased, and women are equally represented as learners in tertiary education in Jordan and Lebanon, areas of focus for further work entail gender-sensitive curricula, textbooks and teacher training; addressing the gap between women's education and participation in the workforce; addressing gender stereotypes regarding perceived suitability of types of employment; equal pay and women-friendly work policies; and promoting women's leadership across all domains.

Media not only reflects social values but there is empirical evidence supporting the assertion that it also informs and influences those values. ${ }^{23}$ However, behavioural change as a result of media messages (or campaigns) does not necessarily follow, for a variety of reasons. But research suggests that even if individual behaviors are not changed, media exposure to various issues can act to prime audiences, which eventually has a longer-term effect on attitudes. This subsequently makes it easier to introduce policy changes, as these are more likely to be accepted by the general public. ${ }^{24}$ This has the implication for LANA that the initiative is contributing to an 'influencing' environment that can be evaluated not only in terms of the number of individual 'changemakers' but also a broader change in the 'socio-political climate' over the longer term, as with media campaigns. This may take the form of both more functionalist or conflictual models of social change, as described in the preceding section.

Another important aspect of the connection between media and social change is the concept of representation. 'Representation connects meaning and language to culture', ${ }^{25}$ and with these generally shared connections we are able to interpret our surroundings. In this way, media representations have a cultural aspect, as our culture informs our understanding of mediated messages and vice versa. Mediated representations have a discursive nature, which help link certain issues to certain symbols, or give certain knowledge power or legitimacy over others in a certain historical, cultural context. This helps define issues, alternatives and how we discuss them.

Studies on women's representation in the media show that the presence of women creatives behind the scenes affects storylines and the representation of gender on-screen. ${ }^{26}$ For example, when women are working in powerful positions behind the scenes, there is a greater number of female characters on screen. ${ }^{27}$ The presence of women behind the scenes not only affects the proportion of women and men onscreen; it also affects the manner in which they are presented. More females behind the scenes meant that

\footnotetext{
${ }^{20}$ UNESCO, 2015a.

${ }^{21}$ UNESCO, $215 b$.

${ }^{22}$ Drafted by Dina Kiwan, American University of Beirut.

${ }^{23}$ Happer and Philo, 2013.

${ }^{24}$ Happer and Philo, 2013.

${ }^{25}$ Hall, 1997; p.1.

${ }^{26}$ Lauzen et al., 2001; Signorielli, 2012.

${ }^{27}$ Gerding and Signorielli, 2012.
} 
women characters had more assertive speaking roles and were more verbally active. ${ }^{28}$ While the aforementioned studies were carried out in the US, the same trends are apparent in other parts of the world, as is the case with Middle Eastern television. One study of satellite programmes in the Middle East showed that more female writers meant more equal numbers of male and female characters, as well as fewer stereotypically gendered portrayals. ${ }^{29}$

It is not only politicized media campaigns that prompt awareness and change in society. Using entertainment media (e.g. soap operas, films, chat shows) can be an even more effective way of bringing taboo issues to the forefront. One example entails the use of locally produced media in Lebanon (in this case, film) as a means for discussing taboo issues, such as sexuality. Women who fear repercussions from society when discussing taboo issues may feel safer discussing these issues in relation to a mediated representation. It is suggested that this kind of tool both allows for safety in voicing opinions, and may also lead to social change. In addition, there is empirical evidence to support the idea that local adaptations may provide more avenues for social change than imported media, allowing audiences to discuss issues that are relevant to their own lives. ${ }^{30}$

\section{Methodology}

Interviews with 'stakeholders' were conducted in each of the three country sites - Lebanon, Jordan and $\mathrm{KRI}$, where interviews were held with 24,10 and 12 stakeholders respectively. Stakeholders working in the fields of gender equality, women's rights, and women's participation and leadership, broadly construed, were identified through initial desk research on the internet and social media, as well as through the research project's advisory board and researchers' own networks in the field. Interviews typically lasted one hour, and were semi-structured in format in order to explore individually the range of issues as outlined in the research questions (see Appendices 4 and 5 for stakeholder and focus group interview schedules).

In addition to stakeholder interviews, focus groups were held with women and men separately, in Lebanon, Jordan and KRI, with a total of 24 focus groups in Lebanon spread across four locations (Beirut, Mt Lebanon, Saida and Nabatieh); 11 focus groups in Jordan spread across two locations (Amman and Zarqa); and seven focus groups in Erbil. The breakdown between male and female focus groups at each location can be found in the table in Appendix 3.

Given the scope and scale of the project, it is important to note that the findings do not claim to be representative of all stakeholders in the three countries; nor are the findings emerging from the focus groups representative of the views of all men and women in these countries. Rather the aim of this qualitative project is to explore $a$ range of views expressed by stakeholders and ordinary men and women in the three countries, in order examine the ways in which gender equality is manifested in people's lives and to reflect on social change mechanisms, in particular moving from change at the individual and personal level to the societal level. In addition, it should be stated that the study's findings are relatively more limited in relation to its ambitious objective 2: 'analysing the chain of changes in perceptions and attitudes on gender equality from the individual sphere to the social and political spheres and from local to national level'. There is a great deal of theoretical literature as well as many large-scale studies on social change, so it is important to contextualize the findings from this small-scale study conducted over a period of a few months. What the project illustrates is the highly complex nature of social change and its contested nature among different actors, highlighting the need to design more sustained and focused methodologies to examine this phenomenon in greater detail.

\footnotetext{
${ }^{28}$ Lauzen et al., 2001.

${ }^{29}$ Kharroub and Weaver, 2014.

${ }^{30}$ Haidar, 2011.
} 


\section{E. Research findings: Lebanon, Jordan, KRI}

The findings are presented below by country, compiling stakeholder and focus group participant views around a number of core issues discussed in the interviews. These include participation, and views on levels of participation, leadership, gender equality, social change, obstacles and opportunities, views on successful strategies and stakeholders, and finally, recommendations. Interpretation of the findings is related to key ideas highlighted in the literature review section. It is reiterated that the findings do not intend to make generalizable statements on the views of all stakeholders and ordinary people in the three countries, but rather aim to identify a range of views and perspectives on people's lived experiences of gender equality, participation in society and perspectives on social change.

\section{Intersectionality}

Stakeholders and focus group participants commented on the need to take into account the very different lives of women across Lebanon, Jordan and KRI, not only in relation to location, but also in relation to the urban/rural divide, age, class, religion/sect, nationality and sexuality. Intersectionality is a complex concept that relates to both structural and political intersectionality. ${ }^{31}$ Invoking intersectionality raises debates about treating categories as stable rather than fluid and amenable to change. It also raises a debate as to whether to focus on 'groups' as opposed to focusing on the social or power relations between them. An exclusive focus on marginalized groups can ignore the power relations between the 'marginalized' and the 'powerful' in society. This is both an academic and practical debate, with implications for how to organize institutionally in best addressing inequalities. Is it best to focus on specific intersections of inequalities with specific laws, or should there be more general laws and policies that are more inclusive? These intersectional themes are highlighted in findings across the three countries, although it should be noted that given the scale and design of the project, such comments are not generalizable.

\section{Lebanon}

\section{Stakeholder and focus group participant views}

In Lebanon, 24 stakeholders were interviewed and included representatives from a range of NGOs and political parties, as well as individual activists, academics and writers. A total of 24 focus groups were conducted, six in each of the four different regions of Lebanon: Beirut, Mt Lebanon, Saida and Nabatieh. (Please see Appendix 3 for the full list of stakeholders and focus group participants.)

\subsection{Participation}

When asked about their understanding of participation as a concept, stakeholders and focus group participants all asserted that participation for women entails participation in both the private and public spheres. In particular, the importance of economic participation was emphasized. Yet a common theme across both stakeholder and focus group interviews was the notion that for women to participate in the public sphere they have to take on more roles than men, e.g. working and taking care of household duties. Outside of Beirut, women tended to focus on the difficulties of participating as married women. As one woman in Mt Lebanon put it, 'I come from my job to my second job at home; from work to work. It's also his child; he should help out and participate.' Or the image offered by a woman from Saida: 'When you compare men to women, it's like one is holding one watermelon, and one is holding 10.' Given that women's participation is accepted in terms of a limited instrumentality rather than deeper attitudinal change framed in terms of equality or justice, the implications for the LANA project are that this suggests the need for increased focus on education and media or awareness-raising, going beyond instrumental reasoning.

These findings reinforce previous empirical research findings, and in addition illustrate an understanding of women's participation that is premised on a conception of gender underpinned by functionalist approaches

\footnotetext{
${ }^{31}$ Walby et al., 2012.
} 
- i.e. where gender differences are conceived as contributing to social stability and cohesion through ascription to male (public) and female (private) spheres, with an implied naturalness to gendered roles and this form of societal organization. The acceptance of women in the public sphere is primarily economically and instrumentally driven rather than values driven, not because the male 'accepts and is avant-garde, but because he can't afford to support a family on his own', according to one female focus group participant. The implications for the LANA project are that such an initiative provides a learning opportunity whereby men and women can reflect on the constructed nature of their gendered lives and consider whether it meets either their instrumental/economic needs or their broader values of equality and justice.

There is, nevertheless, a growing recognition that gender differences arise from differential socialization into learned gender roles, which are socially constructed. In the female focus groups, women were concerned that participation should be about more than visibility or greater representation, and that it should be 'real' participation with women having a role in decision making; similarly, stakeholders talked of women being 'actors for change'.

The importance of taking an intersectional approach to understanding the range of views emerging from focus group participants in particular, is evident in the different views of men and women. Men tended to express pride in their perception of Lebanon as comparing favourably both to other countries in the region and to the West in terms of women's rights. This was more striking in Saida and Nabatieh, where men also expressed the belief that women have more rights in Lebanon than in other countries in the region, and that women are shown greater respect in this region than they are in the West. Essentialist constructions of gender differences were also expressed, where men referred to what they perceived as women's 'more emotional nature' which explained why they 'prefer staying at home'. Although recognizing some structural issues, men tended to make women responsible for their own lack of participation, saying that that it is up to women to participate and that there are no tangible barriers to their political participation. In contrast, however, while women also focused more on personal and societal issues in relation to the issue of women's participation, for them, husbands' attitudes and family limitations on mobility were raised as significant obstacles to their participation. ${ }^{32}$

\section{Levels of participation}

A sizeable number of stakeholders expressed a perception that levels of participation for women have declined over the last five years, and this was attributed to political instability, increased poverty and the 'Arab Spring'. While the protests on the streets across the Arab world initially provided an opportunity for women's participation, and improvements have been noted in some Northern African countries, such as Morocco and Tunisia, women have been subjected to violence by authorities in some countries. On the other hand, stakeholders believed that there is higher visibility and a greater level of advocacy and positive media coverage for issues of women's participation and leadership, gender equality and violence against women compared to 10 years ago. These perceived changes were attributed to changes at international policy levels (e.g. Beijing +20 review and CEDAW were cited as important) and to a certain extent at regional and national policy levels.

In general, focus group participants perceived that there had been improvement in terms of women's participation, although women's severe lack of representation in the political sphere was noted by both men and women. Women's participation was thought to be increasing in the private sector, with more women visible in managerial or board roles. Yet women expressed frustration that greater visibility of women in these roles did not necessarily translate into quality of participation.

Greater participation in education was cited by both stakeholders and focus group participants, with a higher education administrator expressing the perception that there are relatively few obstacles to female students' participation today: 'Before, yes, being on the roads, the fear of the parents, security situation, etc. There is more awareness now.'

\footnotetext{
${ }^{32}$ Obstacles to women's participation are discussed in full in the subsequent section.
} 
Yet, as is also evident in the literature, the significant gap between education and employment was noted. In Beirut, both men and women mentioned improvement in women's participation in areas like banking and marketing, where there are more women in senior positions. In Saida and Nabatieh, sectors such as education and civil society were mentioned as areas where there had been an improvement.

Again reflecting the literature in the field, women's almost complete absence from formal politics was commented on. This was attributed to the failure of political parties to promote women's participation, but most importantly to the fact that formal politics is seen to be a masculine activity associated with war and violence, given Lebanon's civil war legacy and sectarian power-sharing. It was perceived that women have a relatively greater presence in local politics through municipalities, and informally, through CSOs and initiatives. One stakeholder who does regional work on gender observed that when comparing Lebanon and Jordan, 'One of the main things is in political participation; when we look at the indicator of how many women are in Parliament, Lebanon is a failure in comparison to Jordan, and yet if we look at political participation in its many aspects, such as their participation in demonstrations and protests, such as labour movements, the size of their participation and her voice in these movements, you find that women probably are more present in Lebanon. The problem in Lebanon is how to translate women's participation on the ground to more successes on the level of political representation.' That participation in local politics does not translate into participation in national-level politics may be accounted for in part by Lebanon's patriarchal system, which was also perceived to account for women's lower levels of participation in the public sphere in general. In terms of positive comments about levels of participation, some stakeholders noted greater participation in the private sector. In addition, youth movements demonstrate greater participation of women, as evident in the ongoing trash protests.

\subsection{Leadership}

Leadership was distinguished from participation, and described by one stakeholder as an 'acquired skill'. Many female focus group participants had the perception that women must take on or internalize 'masculine' or 'male' traits to be successful leaders. This was often expressed in terms of women needing to take on traits of being 'more assertive', 'more aggressive' and 'less emotional' in order to succeed. As one woman from Saida stated, 'If women aren't authoritative to the point of oppressing, they cannot control in government offices. This is why I prefer when men are in control, because women become overbearing.' Women linked the difficulty of having a leadership role in Lebanon to the dual roles of women (i.e. working within the home as well as in the public sphere), and the lack of community/familial support in a patriarchal society. In contrast, men talked of the perceived 'emotional nature' of women as inhibiting their leadership abilities. Therefore women's perception that they, in effect, need to 'become men' can be seen as a response to their being framed as too 'emotional' or too 'feminine' to be leaders. These findings reinforce discourses not only in this region but also in the West, historically and also to some extent today.

There were also men and women from Beirut and Mt Lebanon who discussed political leadership as having a negative connotation in Lebanon, associated with war, corruption and bureaucracy. The quota system received mixed reviews throughout the groups; the most common perception was that the quota was needed as a temporary, albeit discriminatory measure. When discussing the quota, one male Mt Lebanon focus group participant said that 'women leaders cannot be enforced but have to rise organically'. Female politicians were often seen as proxies for males, or as inefficient, or not working towards women's issues. One MP said, 'There are [women] leaders but we do not shine the light on them. There are in all fields, look in the banking and management fields, but look at Parliament. Unfortunately in Parliament there is not much of a women's role; for example, when we proposed the cancellation of the honour crime law, when the discussion happened there was not a single woman in Parliament, not a single one!'

While it was noted by several stakeholders that leadership has not been institutionalized in the public sphere, examples of leadership can be seen informally at the level of the household, and also within the local community. Within Syrian and Palestinian refugee communities, women have experienced leadership being thrust upon them in extreme conditions arising from, for example, the death of a husband or male relative, or extreme poverty. While such instrumentally driven experiences of leadership may be positive 
for some women, it is often the case that the adverse conditions in which these women find themselves do not allow for a supportive or conducive experience of leadership, given that there is typically no family support. In addition, it is often the case, as attested to throughout history, that once the conditions for participation and leadership are removed (e.g. as a result of improved economic circumstances or the end of conflict), opportunities for women's leadership (and even participation) recedes. This has been attested to in the West, for example at the end of the Second World War, where women experienced significant frustration at having to 'go back home' to their traditional gender roles after having been substantively involved and playing leading roles in the public sphere while their male relatives were absent.

\subsection{Gender equality}

Gender equality was explained in relation to a number of sub-concepts, including equal responsibilities of men and women (in the private and public sphere), equal decision making, equal access to resources, equal pay, being equal in law, and being equal within the family. Socialization into different gender roles was recognized as playing a significant role in undermining gender equality. One stakeholder perceived that gender equality would not be attainable as long as the sexual objectification of women, sexual repression of the population and general taboo surrounding sex is linked to a cultural notion of 'shame', and as long as there is a perception that women embody family honour. Another issue discussed with local populations was the use of the term 'gender' itself, and the fact that this is sometimes problematic. However, when gender is discussed in terms of what it actually applies to in concrete terms, this is more acceptable. Some stakeholders commented on Lebanon's appearance of having relatively greater gender equality compared to other Arab countries in the region, and warned that women's relatively greater presence in the streets and more liberal attire should not be understood as women having greater freedom or more rights; that this is in fact only a 'superficial sense of freedom'.

In contrast to stakeholders generally adopting an understanding of gender as being 'socially constructed' and learned, many focus group participants held more essentialist understandings - that 'a woman is a woman and a man is a man', particularly in Saida and Nabatieh. Women, particularly within Beirut, discussed equality within the socio-economic, civic and political spheres; equality under the law was stressed, for example in the case of citizenship and nationality rights that discriminate on the basis of gender. Outside of Beirut, women tended to focus on the dual role of women in the public sphere and the family unit. Men, both Christian and Muslim, cited religion and culture as inhibitors of gender equality, although Christian men typically attributed more negative connotations to Islam. When challenged, however, they typically acknowledged that similar constraints for women exist in Christian communities, hence attributing these constraints to culture rather than religion per se. Another theme of interest relates to a notion that gender equality must be premised on social equality for all. This reflects discourses that human rights for all is the priority in a context of many being disadvantaged, not just women. While there is a logic to this theorizing, there is a risk that this is a politicized discourse that becomes an obstacle to focusing on gender equality and women's participation, and is in fact the opposite logic to development discourses that argue that women's participation is the key to the development of society as a whole.

Some interesting insights by female Syrian refugees in Nabatieh highlighted the differences that arise when gender roles are challenged due to conflict or war:

'Especially in the situation of being a refugee, the woman is participating in everything with the man; she is working hand in hand with him. The situation has increased her participation. In our Syrian society, women were nothing outside their homes and children, a housewife; now with the displacement you find the woman everywhere. She has more opportunities to work; she can work in more areas then men.'

While the women discussed awareness of issues like early marriage, they also expressed nostalgia for a time when clearly defined expectations for gender roles were not a source of confusion or tension.

What emerges from these findings is that there are differences in understandings of gender and gender equality held by stakeholders and focus group participants. This is more pronounced outside of Beirut, and is reflected in the perceptions of both men and women. 


\subsection{Social change}

Social change was understood to be a complex phenomenon requiring both enabling conditions from topdown - laws and policies to protect women and promote gender equality, civil society, education and media - as well as changing individual attitudes from the bottom-up. It was seen as critically important that social change starts at the level of the individual and 'ripples outwards' through to the family, local community and eventually society. It was also emphasized that it should be remembered that social change takes time.

Social change was generally identified as something that happens slowly, especially with gender issues. While many focus group participants recognized that both change from the 'top' and change from the 'bottom' are necessary, it was thought to be more effective when attempts to bring about social change take a bottom-up approach. Bottom-up change was linked to inclusive movements (stressing the concept of intersectionality) and change from the family unit or home that would then spread to society. For example, one woman residing in Dahieh in Mt Lebanon stated: 'The home is the foundation of society; any change comes from the home. Each home follows or doesn't follow certain customs and traditions; even neighbours in the same building can be different in mentality.' In addition, some stakeholders referred to new forces that enable social change: 'Changing the mentality takes many generations, at least two. We are changing slowly due to secularization and globalization. Due to technology and social media you can no longer hide things, there are bloggers and freethinkers. This new technology really helped women and women's issues.'

Syrian refugees in Nabatieh highlighted the complex effects of conflict or war on attitudes and perceptions. They discussed both the perceived benefits and drawbacks of coming into contact with the Lebanese populations through women working due to political and economic hardships, rather than staying at home. They discussed both improvements, such as the perception that early marriage is an issue, and perceived complications, such as the confusing delineation of gender roles.

The findings suggest, and reinforce the literature, that both meta-level and micro-level approaches are necessary in bringing about social change. The findings largely support structural functionalist conceptions of social change where change is perceived as gradual, in order to largely preserve the status quo, in contrast to conflict theory conceptions of social change that see social change as arising from social inequality, where protest is desirable and necessary in order to achieve social change. This data was collected before the trash protests that started in late July 2015, and it would be interesting to see whether different models of social change would be referred to by ordinary people as well as stakeholders, given the changing context. Also important to note is the highlighting of the perceived facilitating effects of education and social media - which can be conceptualized as the link between micro-level change in individual attitudes and macro-level societal change.

Education and media are frequently cited as key drivers of social change. It is proposed that the domains of education and media can be conceptualized as meso-level - the link between personal and societal

change. This is further discussed below in the section on comparative comments and in the recommendations section.

\subsection{Obstacles}

The table below shows the range of stakeholders' perceived obstacles to women's leadership and participation, organized in terms of different levels: personal, societal, structural and strategic. Personal level refers to aspects that can be identified within the person, for example their attitudes, values and personal relationships. Societal level refers to community and societal-level cultures, traditions and norms. Structural level refers to institutional features, for example, policies and laws. Strategic level refers to metalevel features, for example, broader theoretical discourses such as human rights discourses or perceptions of Western agendas. It should be noted that these four categories are not completely mutually exclusive, but are a heuristic categorical device to highlight differences in levels of attribution to perceived obstacles, which is useful in understanding how mechanisms of social change move from micro- to meta-levels. As can be seen, stakeholders highlight relatively more structural and strategic obstacles than personal and societal 
obstacles; this could be attributed to the relatively 'elite' position of these stakeholders, who may not experience, or may experience differently the personal and societal obstacles that 'ordinary' women face. It may also reflect Lebanon's context, where women's rights may be more culturally accepted - at least in Beirut, where the stakeholders were predominantly based - even though these rights are not reflected in law (e.g. whereas Jordan and Erbil have political quotas for women, for example, but also have more conservative cultural attitudes).

Stakeholders emphasized a range of structural obstacles which include a lack of institutional access and lack of laws to protect women, as well as women's equality not being a governmental priority. While women have access to courts, a distinction was made that there is no equitable access to justice. Strategic obstacles raised include lack of solidarity between women, lack of coordination, and off-putting terminology and competing discourses. Relatively fewer societal and personal obstacles were mentioned by stakeholders, but these included poverty, security concerns, family pressures, sectarianism, a lack of democracy, and an undeveloped concept of citizenship. (For full results, see tables in Appendix 8.)

Analysis of obstacles is by region in Lebanon, offering a comparison of the general themes shared by men and women in the focus groups. While women tended to offer more personal or societal obstacles that affect their daily lives, men focused less on the personal. Women referred to notions of honour, shame and guilt - strong emotional levers used in their personal lives and in society and by the state to maintain a sublevel citizenship. In the southern regions, the husband himself or husband's expectations were also mentioned as obstacles to women's equality and participation. Religious interpretations and society's expectations of women to fulfil multiple roles (as opposed to sharing roles with partners) were also mentioned as societal obstacles across the women's groups. Male groups were more likely to mention media or the misinterpretation of religion as obstacles. Saida and Nabatieh groups also had more commonalities than the other regions, such as the belief that NGOs pay insufficient attention to the local context. (For full results, see tables in Appendix 8.)

\subsection{Opportunities}

Stakeholders highlighted far fewer perceived opportunities in comparison to obstacles, and also fewer compared to focus group participants. Both stakeholders and focus group participants noted societal-level factors, including the vibrancy of Lebanese civil society; both also referred to the role of youth in civil society. Related to this was the potential of the younger generation, which is particularly important given the large youth populations, not only in Lebanon but across the Arab region. As such, the potential of education as a domain for socio-political transformation is recognized as critical. Education can be conceived of both as a structural-level opportunity, in that education is a space where the nation's objectives and values are transmitted, but it is also a site of potential transformation, and thus has the potential to play a critical role in social change as a meso-level mechanism between personal/family-level attitudes and values and larger scale societal change.

Media, social media and advertising campaigns were also highlighted by both stakeholders and focus group participants as opportunities, although focus group participants expressed some ambiguity/tension, with media perceived also to play a negative role. Similarly, media and social media, like education, reflect society's values and attitudes, as well as providing a space for social transformation. Stakeholders attributed media and social media with creating a more conducive climate for their work, given their role in increasing awareness of women's rights and interrelated issues (child labour; trafficking; sexual health; migrant and refugee rights; Lesbian, Gay, Bisexual, Transgender, Queer, Questioning and Intersex [LGBTQI] rights), as well as greater awareness of human rights. Focus group participants insightfully noted the importance of involving men in initiatives, and saw potential in working with international NGOs. Only some men in the focus groups perceived religion to be empowering. As can be seen from the findings above, across both stakeholder and focus groups there is general agreement with regards to seeing civil society, youth, education and media/social media as presenting opportunities for social change. Civil society and youth can be seen as the actors helping to facilitate change, with education and media/social media as the meso-level means to bring about this change. 


\subsection{Strategies/initiatives}

Stakeholders and focus group participants both noted a number of strategies and initiatives in Lebanon as pertaining to women's successes in passing laws and raising awareness concerning women's rights. While these ranged from the national to more local levels and from top-down to bottom-up initiatives, of note is that for each, the specific examples mentioned by stakeholders and focus group participants were different, reflecting the varied awareness and concerns of people in different socio-economic contexts.

\section{Positive examples}

For stakeholders in Lebanon, the awareness campaigns in relation to domestic violence had made some modest gains, most notably through the campaign against gender-based violence, 'Be a Man', and the ultimate passing, in 2011, of the Honor Crime Law. There was also mention of the successful effort to amend the law extending maternity leave from 40 to 60 days. Some stakeholders also mentioned how training sessions aimed at increasing gender sensitivity (for example, at the ISF - the Lebanese police) or enhancing literacy and ICT capabilities (of refugee women) had also made an impact. These initiatives reflect the need for interventions on both the macro and micro level; that is, while changing laws was definitely seen as crucial in granting women certain rights, this had to be coupled with changing attitudes and behaviours on the individual level as well. As one stakeholder noted, legal change is not enough; there has to be a cultural change as well, and this starts at the level of the individual.

Focus group participants echoed this notion of positive initiatives at both levels. They mentioned a number of successful programmes, citing UN awareness training, the support of the Ministry of Social Affairs in raising awareness on family violence, an effective micro-loan programme (Mashrou3a), a gender and body research journal (Kohl - supported by the Gender and Sexuality Resource Centre [GSRC] and the Arab foundation for freedoms and equality (AFE), and the establishment of a female quota system by the Kataeb party. They also noted that while significant involvement of women in politics at the national level was still lacking, campaigns to involve more women at the municipal level and in political parties have been effective and require further support.

There was frequent mention, by stakeholders and focus group participants, of one initiative that, despite consistent efforts by various women's and other groups, has remained unsuccessful to date: the right of women to pass on their nationality to their husbands and children. As one stakeholder stated, 'Imagine a presidential candidate (woman) married to a non-Lebanese, who would not legally be able to pass her citizenship to her children!'

\section{Lessons learned}

Stakeholders in Beirut spoke often of the need for more efforts that work top-down, such as establishing a Ministry (and not a committee) of Women that includes women as decision makers, to set an example to other women and demonstrate that political participation is not exclusively a male domain. Through such political leadership, decision makers would also demonstrate a commitment to women's issues. Many also said that a quota system was needed for Lebanon, to begin making women's involvement in politics more visible, but only as a temporary measure (a point also stated by many focus group participants, who perceived quota systems to be degrading, but instrumental as an intermediary strategy).

There are now more women involved in public life - at the local, municipal and civil society levels - and many stakeholders feel that this achievement should lead to the realization that there is a need for more women to participate in formal political life as well. For example, one stakeholder mentioned the dissonance in view of women being well represented in the judiciary in Lebanon, 'although there are no women Sharia judges'.

Stakeholders noted that more campaigns and work were needed by international groups in regard to raising awareness on women's issues, and called for increased cooperation of local/national groups with international partners. Focus group participants spoke of the need for more bottom-up approaches, such as substantial training workshops (including mixed gender) - language training, ICT, etc., rather than focusing on counselling or hairdressing classes. They also mentioned theatre and the arts as avenues for expression. 
While there may be more women involved in political parties and municipal politics, there was not enough dialogue between women in these different venues; more cooperation is needed between them, as well as provision of training and support for women (in leadership, campaigning, using social media, fundraising, public speaking, etc.) to facilitate their entry into public positions. Focus group participants also noted the need for more lobbying and advocacy targeted at political policy makers as a means of continuing work to address laws and policies that still discriminate against women.

\section{Notable stakeholders}

There is an active public sector/civil society in Lebanon, as reflected by the number of groups mentioned by stakeholders as making an impact with regards to women's issues. Stakeholders mentioned many examples of groups who have been visible - with varying degrees of success - over the past few years, including: ABAAD (Resource Centre for Gender Equality), The National Committee for the Follow up of Women's Issues (CFUWI), College Louise Wegmann (CLW), Collective for Research on Training and Development Action (CRDTA), Economic and Social Commission for Western Asia (ESCWA), Al Jam3iyat Haqooq, KAFA (enough) Violence \& Exploitation, Marsa, National Commission for Lebanese Women (NCLW), Red Cross, United Nations Population Fund (UNFPA), Women in Front (WIF) and the Young Women's Christian Association (YWCA). On an individual level (as one participant noted, 'we need more positive role models'), MP Bahia Hariri was mentioned as an example of a strong female politician and one who has been associated with women's issues.

Focus group participants noted many of these same key groups as having made an impact - KAFA, ABAAD and added others whose work on local and municipal (and not necessarily national) issues make them more visible at the local level: GSRC, Marsa, Social, Humanitarian, Economical Intervention for Local Development (SHIELD), UNHCR, UNICEF, Caritas and the Kataeb party. They also mentioned women such as Strida Geagea (MP), Leila El Solh (philanthropist), Nada Debbes (designer) and Zaha Hadid (architect) as women who serve as role models due to the success they have achieved in public life.

\section{Jordan}

\section{Stakeholder and focus group participant views}

Ten stakeholders were interviewed from a range of NGOs, as well as individual activists, academics and writers in Amman. Eleven focus groups were conducted in Amman and Zarqa. (Please see Appendix 3 for the full list of stakeholders and focus group participants.)

\subsection{Participation}

For stakeholders, the concept of participation was tied to four levels: economic, social, political and legal, and there was discussion about how women participate across the spectrum, in both the public and private spheres. Stakeholders commented on the importance of other identity markers that affect women's participation and leadership, such as class and religion, age, marital status and location (urban/rural). These have an impact in a number of areas, such as the ability to claim rights (in divorce), the areas where women's work outside the home is viewed as acceptable, and awareness and acceptance of gender equality. Working intersectionally between gender and sexuality (the rights of LGBTQI persons and women) was also mentioned.

Focus group participants, as in Lebanon, also highlighted the tension in women's dual responsibility in both the private household sphere as well as the public sphere. For many, participation outside the home was dependent on education and implicitly linked to socio-economic class; education was seen as a means to gain access to participate in different areas of public life. When asked about the participation of refugees, both stakeholders and focus group participants perceived this as difficult or even problematic conceptually, as the focus for refugee women was often on survival. For refugees who have been in the host country for long periods, the notion of participation was seen as an opportunity, as a means to incorporate the new skills that refugees might bring to the different arenas of participation. 
As in Lebanon, women's perceived 'emotional nature' was a significant theme arising from the focus group discussions in both Amman and Zarqa. Male focus group participants often expressed the belief that the profession of teaching is the most suitable form of participation for women, as it allows them both to work suitable hours (and with children) while not neglecting household or family duties. As did several Lebanese women, a woman from East Amman complained about men not sharing household responsibilities: 'My husband does nothing in the house, he comes to prove his presence and then he's gone; a morning and evening punctuation.' A male from East Amman couldn't imagine a wife asking her husband to help with housework: 'Can you imagine, just imagine, a woman telling you to go do the dishes? Can you imagine?'

As in Lebanon, the findings illustrate that participation is understood in relation to a conception of gender that is underpinned by functionalist approaches, where gender differences are conceived as contributing to social stability and cohesion through ascription to male (public) and female (private) spheres, with an implied naturalness to gendered roles and this form of societal organization. There is relatively less recognition of the constructed nature of gender roles in the focus groups, although this is recognized by stakeholders. In terms of implications for the LANA project, this again emphasizes the importance of education and awareness-raising in its programmes with both men and women to enable them to reflect on these constructed gender roles in a process of attitudinal change, going beyond instrumental reasons for women's participation for economic purposes, in order to bring about sustained change. ${ }^{33}$

\section{Levels of participation}

Many stakeholders expressed a belief that the situation is better now than it was 10 years ago, and provided examples of women as government ministers, particularly in the culture and education sectors. The general consensus within the focus groups also was that there has been improvement overall in women's participation in Jordan. Participants noted that support and awareness was growing for women's issues, although the pace of change is slow. For some stakeholders, levels of participation were seen to have remained static or even to have regressed, with allusions made to a lack of substantive change with respect to societal attitudes and a rise in religious extremism. With regards to women's political participation, stakeholders commented on how women's perceived abilities were often subject to public scrutiny in a way that men's were not. Women focus group participants in Amman felt that although women were more visible in politics than before, they still did not have sufficient decision making positions or roles. One young woman in West Amman stated:

'Here we have the quota system in Parliament, [but] we still have never seen a [woman] minister of interior or of foreign affairs. We have one for human development, nothing effective or that makes a difference with decisions.'

While many stakeholders acknowledged that there were greater numbers of women being educated now than ever before (approximately 54 percent), they lamented the gap between education and employment, as has been noted in the empirical research literature. In particular, they commented that women are underemployed in a number of areas, including media and unions, especially in the higher echelons of managerial and decision making roles. In Amman, greater participation by women in higher education was also mentioned. Groups in both areas perceived economic hardship to be the main motivating factor for women to work. Zarqa focus group participants perceived that there had been improvement overall in Jordan over the past couple of decades, but perceived women's participation in Zarqa to be low and that the government is not doing enough to help.

Some male focus group participants attributed a perception of rising levels of divorce to women's participation outside the home. In their view, women's participation in the public sphere would inevitably lead to their neglect of household responsibilities and ultimately cause friction in the home, which could

\footnotetext{
${ }^{33}$ As mentioned previously, this is also supported historically where women's participation and leadership in the public sphere during times of war, conflict or economic hardship is reversed once the instrumental reasons that led to women's public participation have been removed.
} 
lead to divorce. While men in the Amman focus groups mentioned greater awareness and more economic and social programmes creating slow change, men from the Zarqa focus groups discussed perceived 'suitable' jobs for women, such as teachers, as well as the concept that women are not always capable of participation or leadership.

\subsection{Leadership}

This concept was understood by stakeholders as making a difference either in the private sphere - such as the family or village life - or more publically and on a national level. It was tied to the ability to make decisions. Many stakeholders mentioned the quota system in Parliament (10 percent seats for women) and municipalities ( 25 percent seats for women) reflecting women's more visible leadership roles. There are now 18 women in Parliament (11.5 percent), and three political parties (out of 33) led by women. Leadership roles for women, according to many stakeholders, were most often in the education field, with glass ceilings in many other domains. One factor limiting leadership, according to stakeholders, was perceived worthiness; women constantly had to prove themselves worthy, whereas men did not face any such pressure. So while participation of women, particularly in the public sphere, was for many significantly better now, women in leadership positions were less common and were circumscribed to certain fields, such as education.

The perception that women are 'emotional' in nature and that this affects their ability to lead or participate was mentioned by many participants, both women and men. This relates to the notion of 'worthiness' referred to by the stakeholders. Women generally noted that more effort is required of them to succeed in order to be deemed effective leaders; the idea that women must have strong personalities to lead was also mentioned. Family and societal attitudes were seen as obstacles to women's leadership positions, while male support was seen as necessary for women to take up leadership roles. As in Lebanon and Erbil, women often considered women leaders to be proxies for males: 'Decision making positions here are limited to men, even the woman who is a leader has a man above her.'

\subsection{Gender equality}

Gender equality was seen as existing in law in the abstract; however, in practice, few women own property in Jordan, and they inherit less than men according to Sharia law. Stakeholders talked of how families often discourage their daughters from claiming their inheritance, as this is perceived to be taking a share away from their brothers and male relatives. The perceptions among many stakeholders were that none of the laws are discriminatory with respect to gender; rather it is the lack of equal opportunities for men and women in work that are constrained, for example, by societal and family concerns about women travelling alone in public, especially at night, and the lack of sufficient and reasonably priced childcare. Yet some stakeholders did express that it is politically impossible to challenge anything that is contained within Sharia law, for example, inheritance laws.

Some stakeholders as well as many focus group participants mentioned that men were entitled to request that their wives not work, and even to prohibit them from working outside the home. Although this is not written in law, it can be stipulated as a condition in marriage contracts. There was also mention that 'children belong to the father' so the father passes on the Jordanian or other national identity. While Jordanian women married to non-Jordanians do not have the right to pass on their nationality to their children, there have been recent changes in law where the children of Jordanian women can claim civil rights - for example access to education, healthcare and employment. This was deemed be perfectly reasonable by one male stakeholder as well as many focus group participants, both male and female. The view of Jordan being more advanced than other Arab countries with regards to gender having been introduced into the school curriculum and teacher training was also common, although one stakeholder noted that although there is this perception, it does not match the reality.

The concept of gender equality was met with mixed reactions by the focus group participants. Many, especially those in Amman, expressed support for justice or fairness, but not necessarily equality. This related to the idea of 'equal but different', drawing on essentialist notions of men and women being inherently (and biologically) different, and hence the need for different and circumscribed gender roles in

26| P a g e 
society. Women tended to focus on legal inequalities that favour men, such as nationality laws. Some expressed support for the notion of equality in the abstract, but when discussing careers held beliefs that there were certain jobs that women are not suited to.

In contrast, men tended to view gender equality as a Western concept and not applicable to the Jordanian context. They expressed the belief that religion supports equality, but again in terms of 'equal but different', stating that women are best suited to being at home rather than in the public sphere. They also had a common perception that women have sufficient rights, and that practices in Jordan preserve femininity and honour for women rather than oppress them. In the West, on the other hand, women were purported to have relatively fewer rights and to be more objectified than Jordanian women. In Zarqa, the notion of women wanting or asking for too much was raised, as well as the idea that it could create conflict. According to one male focus group participant in Zarqa: 'It is wrong for us to give the woman more than what is her right; God created humans as greedy, so if you give her rights she will take yours as well, she will keep demanding, demanding, demanding, until one day she will come and say, "I want to be head of government, and this is happening!" ... in the end she is a female, not a male, she shouldn't go and work in the jobs of a man... there should be restraints for women. Let us say 50 percent for the man and 50 percent for the, or 60 percent for the man and 40 percent for the woman, is a percentage that is enough for the woman to live a happy life; this is the point of women's liberation, that she is satisfied in her life, she shouldn't go and demand things that are not for her, just because she can.' Another young man asked: 'What more do they want?'

\subsection{Social change}

Social change was seen as multifaceted, involving changing attitudes and laws, and combating religious extremism. As one stakeholder noted, 'What good is a quota system when gender-biased attitudes continue to prevail?' While there was confidence that Jordan is open to social change, for many this could only be achieved slowly ('small steps'), by working from the bottom up, involving men, and by starting at the level of individual and family values. Social change was perceived as something that needs to be led by the middle class, that involves youth, and that could involve a lengthy and difficult struggle. Change, especially significant change, takes time.

Focus group participants in Amman, both men and women, cited economic issues as drivers of social change. They observed higher rates of women's economic participation being driven by the need to supplement the household income. Zarqa women perceived change as coming from the individual level, the household and socializing children's values. In Amman, again the belief that social change is a long, slow process was expressed. Education and awareness-raising were mentioned as important factors for social change, as well as more communication among women. As in Lebanon, conceiving of social change as incremental and taking place slowly over time also draws on structural functionalist as opposed to conflict models of social change. This indicates an approach of largely preserving the status quo, but making modest adaptations both through changing laws and changing individual, family and societal attitudes and values.

\subsection{Obstacles}

The first table below illustrates obstacles to enhanced participation and leadership among women and to gender equality, as perceived by stakeholders in Jordan. These have been categorized at the level of the personal, societal, structural and strategic, as for Lebanon. Jordanian stakeholders, like Lebanese stakeholders, emphasized structural obstacles, but in contrast to Lebanese stakeholders placed relatively greater emphasis also on societal obstacles. Structural obstacles included institutionalized patriarchy, in spite of the presence of women's quotas, which were perceived to be tokenistic rather than a commitment to substantive change. In addition, the resilience of tribal networks, institutionally embedded, was seen to undermine a concept of citizenship for both men and women. The lack of affordable support services, such as childcare services, and the lack of prioritized funding for women's rights and gender equality issues were also identified as obstacles. (For full list of obstacles, see tables in Appendix 8.) 
Focus group participants in Amman and Zarqa emphasized personal-level obstacles, in contrast to stakeholders. The most frequently mentioned obstacle across regions and genders was the perception of women's 'emotional nature' affecting decision making and suitability for certain types of careers. Other common themes included men's attitudes, the pressure of dual roles, and perceived threats to men and the household. Men were more likely to mention tribal customs as an obstacle, while women explored the concept of shame in Jordanian society. Of note is that structural obstacles were rarely mentioned and in some cases were entirely absent from the discussion. This may be attributed in part to lack of knowledge and/or perceived remoteness of such policies and laws from ordinary (and in some cases very disadvantaged) women's and men's lives, and in part may also be attributed to a belief that laws are not discriminatory against women.

\subsection{Opportunities}

As in Lebanon, stakeholders and focus group participants highlighted fewer opportunities than obstacles. Relative to Lebanon, both stakeholders and focus group participants perceived their societal context to be particularly difficult, expressing frustration at the perceived slow rate of change, noting relatively few perceived opportunities. The opportunities most often referred to included education, the media (to raise awareness), and the involvement of men campaigning for female participation and leadership. Social media was also mentioned, as the sharing of information among groups was perceived as being facilitated by social media and made more efficient. Queen Rania was also mentioned as a role model, as an example of women's participation and leadership, although in some cases she was seen as an 'exception'. Her royal NGOs were perceived to be successful in providing opportunities for women, a perception which may in part be explained in terms of their 'branding' and visibility.

\subsection{Strategies/initiatives}

\section{Positive examples}

A number of positive strategies already in play were noted by stakeholders, as well as initiatives requiring more work, and recommendations for moving forward. Stakeholders focused less on government successes than did their counterparts in KRI; however one government initiative was mentioned - the creation of two permanent committees for women, one in Parliament and one in the Senate. Government-related NGOs such as the Jordanian Hashemite Fund for Human Development (JOHUD) and the Queen Rania Foundation (QRF) were noted as making a difference. The QRF leadership academy and leadership enhancement mentoring programme were cited.

Other successes included human rights toolkits and the provision of legal support for women in divorce cases. Unlike in Erbil, economic empowerment programmes were seen to be effective, including support for women in starting businesses. On the media front, the 'No Honour in Crime' Facebook campaign was named several times. A stakeholder working on LGBTQI issues stressed the success seen in the discontinued use of the word 'shawath' (perversions) by most of the Jordanian media to refer to the gay community, and its replacement with the use of the word 'mithliyeen' (homosexual).

Stakeholders often mentioned the need for more work on laws, especially in relationship to Law 308 on rape, and to laws on citizenship and early marriage. As did their counterparts in KRI and Lebanon, stakeholders perceived that in order for women's issues to advance, it is necessary to increase pressure on the government, coordination between CSOs and involvement of religious leaders, in addition to improving school curricula and the training of teachers for the younger generation.

Focus group participants cited several positive examples of initiatives which largely focused on public awareness and women's empowerment programmes. Awareness sessions and trainings by Sisterhood Is Global Institute (SIGI) and by the Princess Basma Foundation, and some within LANA, were mentioned. A plumbing course for women was seen as highly effective in empowering women in the household: 'This knowledge has given us a sort of authority in the house.' Economic and legal empowerment programmes run by the Jordanian Women's Union (JWU) were also noted, as were micro-financing projects by the 
Women's Fund. For political participation the quota was seen as essential and somewhat successful, yet many took issue with the women who were assigned to the seats.

\section{Lessons learned}

Stakeholders in Amman often referred to the need for more top-down efforts; that is, having key people high up in government who support women's participation and leadership, having a watchdog in the Cabinet charged with supporting and protecting women's issues in decision making, more advocacy campaigns, civil laws, and the development of a legal framework for shelters for women experiencing domestic abuse. As in Lebanon, training and capacity-building programmes were recommended for women, refugees and youth. However the concern about whether these empowerment initiatives are successful, as was common in KRI, was mentioned. This reflects the perception that individual change in attitudes and values in the population is also seen as important. This was notable in calls for increasing the role of unions and encouraging fathers to be more involved in raising children. A suggestion from the LGBQI stakeholder was to form strategic alliances between LGBTQI rights and women's rights for greater exposure and acceptance; yet this interviewee noted a lack of success to date, as women's organizations tended to perceive alliances with LGBTQI to be detrimental to their cause.

Focus group participants perceived shelters for abused women as largely unsuccessful (as in Erbil also). As did the stakeholders, focus group participants referred to laws that were not changed, such as the failed initiative surrounding the nationality law campaign or other initiatives dealing with Law 308 . Women suggested the need for awareness training for men.

\section{Notable stakeholders}

Royal NGOs such as the Queen Rania Foundation and the Princess Basma Foundation were noted as successful due to the maturity of the establishments and government support. UNRWA was noted as successful in its empowerment work and education for refugees. The Jordan River Foundation, JOHUD, JWU and a few female politicians were also cited as positive contributors. Focus group participants mentioned the Committee of Women's Rights, JWU and JOHUD. A person considered to be making a difference is Asma Khader (a female politician working on women's issues).

\section{Kurdistan Region of Iraq}

\section{Stakeholder and focus group participant views}

In Erbil, 12 stakeholders were interviewed, and included representatives from a range of NGOs, development agencies, women's organizations, academics, and government ministries and councils dealing with issues related to women, education, human rights and refugees. Seven focus groups (four female, three male) were conducted in Erbil, with participants ranging in age from 20 to 60 years, and including Kurdish and Christian (Assyrian and Chaldean) groups, members of unions and volunteers working for NGOs. Intersectionality is evident in the differences in perceptions of the different religious groups, but also within religious groups, with intersections with class and also regions of Kurdistan, differing in language/dialect and regional links and histories: 'We can't compare women in Erbil and Sleimaniye to other places, such as Soran. Over there if a woman wears trousers her brother may beat her up in the street.' (Please see Appendix 3 for the full list of stakeholders and focus group participants.)

\subsection{Participation}

Women's increased participation in all spheres was conceived of as both necessary for women and linked conceptually to social development as a whole by both stakeholders and focus group participants.

Stakeholders defined participation as economic and political, yet heavy emphasis was placed on the private sphere. Stakeholders commented on the need to take into account the very different lives of women across $\mathrm{KRI}$, not only in relation to location but also in relation to the urban/rural divide, age, class, language, regional affiliations/historical links and citizenship status. The political family/party of women also intersects with their ability to participate in political roles. 
As in Jordan, and to a certain extent in South Lebanon, the perception of women as inferior and 'emotional' which leads to them not being taken seriously, as well as restrictions on their mobility due to issues of shame and needing permission from male family members, were perceived to be the largest obstacles to equal participation, by both stakeholders and focus group participants. Violence and abuse continually came up in discussions of participation by focus group participants, indicating a perceived connection. Both men and women focus group participants were also likely to perceive that women in lower-income families and refugees suffer most in regards to rights and restricted participation. Yet women also believed that women's political participation as it currently stands is not substantive inclusion, but rather is 'décor' or window-dressing. In contrast, outside of the domain of formal politics, focus group participants referred to female Pashmerga fighters as examples of women participating in KRI. Women were more likely to discuss the tribal mentality prevalent among men and women in rural areas. Some commented on an increase in women's participation out of necessity in times of war and poverty.

Stakeholders see these perceptions and the lack of equal participation as emanating from gender-biased school curricula, the political system and law, religion and its misinterpretation, as well as tribal and sociocultural norms and traditions.

\section{Levels of participation}

Most stakeholders perceive that there has been progress over the past decade, pointing to women in Parliament and the higher rate of women participating in teaching and education. On the other hand, women are largely restricted to lower-level positions, and women who do have more senior positions are either excluded from decision making or act as proxies for political parties. Stakeholders made the observation that although women have a presence in the white-collar workforce, they are not sufficiently represented in labour unions. Student unions, however, afford women a 'dynamic participatory role', yet these unions reflect political parties that do not directly address women's issues. Women also do not substantively participate in the political process, in terms of either electing candidates or running for office. These observations reflect a context where top-down changes to promote gender equality have been introduced, for example in terms of quotas in Parliament, yet frustration is expressed that these changes do not seem to stem from a principled commitment to the values of women's equal participation and leadership.

Focus group participants talked of a perceived fear of being harassed, which limits their participation. There was some disagreement between focus groups, in both men's and women's groups, as to whether women's participation and leadership had decreased or increased. Some stated that 'things are better than 10 years ago' while others believed that women had been better off before Abrahamic religion or the Islamic conquests. Christian focus group participants tended to perceive that Christian women have more freedom than Muslim women; this was not discussed by Muslim focus group participants, although some criticized the influence of some interpretations of Islam. Both men and women focus group participants expressed the belief that there should be more participation for women across all spheres.

Women's and men's perceptions regarding female participation focused on different aspects, where women felt that they are excluded from public sphere activities ranging from electing public officials to driving. In the media, they are excluded from decision making as well as being censored and exploited. Women are understood to have no role in religion: 'There is no women mufti, all fatwas come from men.' In contrast, male focus group participants often pointed to the large ratio of female students as an indicator of participation, and some also highlighted the recent appearance of women drivers. These contrasting accounts illustrate that men tend to focus on the visibility of women, noting higher visibility in the public sphere, whereas women focus their commentary on the quality of this participation.

\subsection{Leadership}

Stakeholders' perceptions about women's leadership in KRI were largely limited to the political arena and government ministries. Stakeholders perceive a need for more women in senior positions in government, party leadership and higher education. Women's participation in the parties that control the politics of KRI is low. Although there are instances of women succeeding within parties without the help of the quota, this 
is not the norm. Female Pashmerga fighters 'in the mountains' were also seen as leaders who are 'as strong as men'.

Focus group participants talked of how women were often described as being leaders before the emergence of Islam. Both men and women largely pronounced female leadership as rare, and female politicians in KRI as having no real role or decision making capacities; they are often relatives of male politicians: 'In Kurdistan [Region of Iraq], women have barely reached leadership positions. Even if parties or political authorities are forced to put women in leadership positions it is a display for them [to show] that they believe in democracy, women's rights and equality; she is only for décor, nothing else, which means women take positions but don't have the authority to take decisions.'

For female focus group participants, the importance of the private sphere is also stressed: 'Leadership begins at home'. In addition, leadership was seen as a quality, and a quality that women have: 'Leadership is personality, charisma and decision making ability - not a position', and: 'Women will make better leaders; they are not as violent and restrictive, and have a better understanding of women's issues. Successful women usually must withstand personal attacks on their honour.' They noted, however, the practical difficulties women face: 'If she does not submit to the orders of a man, people look at her as though she is unfamiliar, rude and disrespectful', or that, 'Women do not have the right to take decisions.'

Some male focus group participants expressed that: 'It is against Sharia for women to be judges, speakers in a mosque, or a leader; this is because they are emotional and can't take decisions.' Others expressed more support for women's leadership, with reference to the female Pashmerga fighters: 'Women have a major role to play in defending their land, so how can we say she is different from men? If she is capable to hold the big responsibility of fighting and resisting, how can she not be a leader, when many men can't fight like the women in Kobani? In my opinion there is no difference between men and women, but in our society the perception of women is mistaken and denigrating.' It is of note that the KRI phenomenon of the female Pashmerga fighters enables a deconstruction of inherent biological differences between men and women that leads to socialization into constructed gender-differentiated roles.

\subsection{Gender equality}

Although stakeholders generally perceived that KRI was better in regards to equality and participation than other Iraqi governorates, they also largely saw that equality and justice for all has not substantively been translated from theory into meaningful practice. Interestingly, almost all stakeholders stressed the government's outward support for gender equality and increased women's participation; however a number of them questioned whether this is an actual intention or a political 'charade'. As one interviewee asked, 'Where are women's issues in the strategies of ministries and in laws?' Another stated that: 'There is no real want for women to participate in Kurdistan [Region of Iraq] or real work done on including them in decision making and authoritative positions'; 'this is just to appease the Western and American gaze'.

Stakeholders often discussed gender-based violence (GBV) in relation to equality and participation, asserting that working to end it is an important step. Honour crimes were also salient in the discussions, although they did not often raise the issue of female genital mutilation (FGM). Almost all interviewees stressed the difference between Erbil, Sleimaniyeh, Duhok and rural areas. Tribal communities, especially in rural areas, have trouble accepting gender equality. Strong norms and traditions surround gender roles throughout KRI.

Many focus group participants - both male and female - regarded Islam, its misinterpretation, or Muslim clergymen as a large obstacle to gender equality and women's participation. Another common theme is the differential upbringing of boys and girls. One male participant stated, 'If we want the woman to be equal to the man, we should raise her on this idea from day one. Imagine that until now, when a woman gets an ultrasound and it's a girl, the whole family is sad, and she hasn't even been born yet. Women are raised on fear and feeling inferior from birth. This type of upbringing should be gone, and her presence considered equal.' 
Female focus group participants were more likely to question the influence of Islam as restricting women, 'as Christian and Yezidi women are also oppressed', with many seeing the issue as lying in culture rather than religion. Women also were more likely to construct equality in terms of equal opportunities in all fields of employment and wage equality. Safety from harassment was also discussed.

Some male focus group perceived gender equality in terms of the different rights and duties of males and females. Others saw that women's issues are symptomatic of a 'backward society' and are 'interwoven with many other social problems that must be addressed'.

\subsection{Social change}

Kurdish society has experienced at least one extreme change, and the period pre-2003 is seen as distinct to post-2003 (the war, fall of Saddam Hussein, and the establishment of Kurdistan); many interviewees and focus group participants made this distinction. Stakeholders disagreed as to whether civil society plays a large enough role in change; some saw CSOs as agents of change, while others saw that they were not doing enough or working only on surface issues. The notion that the social and cultural environment and attitudes are more in need of change than specific rights and laws was common. Another issue that arose in the discussion of social change was that the socio-political regional context and the influx of refugees and internally displaced persons impacting Kurdish society must be taken into account. Education and curriculum improvement, work with youth, legal change and change in the media are seen as steppingstones to social change.

Focus group participants largely perceived change as beginning in the family and educational institutions, showing an individual to collective model, with both men and women seeing social change as slow. Both men and women from the focus groups noted the positive influence that women's relative freedom of movement among the Syrian refugee society has had on Kurdish women, encouraging them to emerge more into the public sphere and take up private sector work. Female focus group participants were more likely to express the desire to challenge society: 'Even if we don't benefit from challenging them [patriarchal societal norms], future generations will. Traditions and customs that restrict women's rights should be broken.' This differs from views expressed in Jordan and Lebanon - which were conceptually closer to a conflict model of social change, where the status quo is more radically challenged. It is possible that the presence of the role model of the female Pashmerga fighter influences this approach to thinking about social change, in addition to the frustration expressed that there has been relatively little substantive attitudinal change accompanying legal changes in relation to gender equality. However, further analysis is required to investigate this proposed link in thinking about social change. Male focus group participants noted that initiatives and women have not been able to change men's minds, which they attribute to dominant attitudes in tribal society. Education is implied as a possible opportunity: 'The thoughts of a man regarding women's rights and participation differ according to his intellectual level.'

\subsection{Obstacles}

The table below shows the range of obstacles to women's leadership and participation discussed by Erbil stakeholders. They are organized in terms of different levels: personal, societal, structural and strategic, with the greatest number of obstacles identified as societal and strategic. Cited obstacles include the party political system and the security situation, as well as a wider perception that politics is a gendered arena not suitable for women - as was also noted in Lebanon. In addition, conservatism, religion, violence against women (both in the public and private domain), women's perceived inferiority, and gendered practices of FGM, honour killings and early marriage were all mentioned as obstacles. As in Lebanon, a number of strategic obstacles were referred to, including a lack of solidarity between women, a lack of coordination between initiatives, funders not understanding the local context, funding deficits due to prioritization of the security situation and refugee needs, as well as concerns about perceived 'off-putting' terminology of CEDAW and 'gender'. (See Appendix 8 for full list of obstacles.)

As in Lebanon and Jordan, in contrast to stakeholders, focus group participants placed a relatively greater stress on personal-level and societal obstacles to women's leadership and participation, rather than structural obstacles. This suggests, perhaps, a relative gap in understanding among stakeholders and a 
tendency to underestimate the personal and societal obstacles faced by ordinary men and women in society. Personal-level obstacles reported by women include emotional inhibitions of fear, shame and honour, arising from the perception of transgressing cultural, traditional and religious norms. The husband, as in Jordan and in South Lebanon, is perceived to be a main obstacle for women, yet women also recognized that women's own beliefs and attitudes can be obstacles to their participation and leadership. Men also referred to notions of family honour and shame, and reported fear for women's physical security - both outside and inside the home. This may represent a genuine concern for women travelling alone given the security situation, yet it can also be interpreted as an inhibiting discourse used as a means of controlling women's freedom of movement through fear. Men also expressed the perception that women are too emotional and therefore are ill-suited to decision making. Women referred to a range of societal obstacles including religion and conservative clergy, fear of ISIS, perceived widespread gendered abuse, sexualization of women and concerns about family reputation. Men also referred to religion and tribal norms, but also noted poverty, lack of education and sexual repression. (See Appendix 8 for full list of obstacles.)

\subsection{Opportunities}

As in Lebanon and Jordan, stakeholders presented far fewer opportunities in comparison to obstacles in the woman's struggle. In comparison to Lebanon and Jordan, structural-level features were highlighted. These included the quota system, and the government's apparent stated support for gender equality and promoting women's participation and leadership. In addition, strategic international and government initiatives such as CEDAW, the High Council for Women's Affairs, The Ministry of Interior's Department to Combat Violence Against Women (DCVAW) and the Ministry of Education's Equal Opportunity between Genders Committee, were highlighted. Of note is that the potential of education was emphasized, again echoing findings in Lebanon and Jordan, and supporting a theory of social change whereby education is a domain for social transformation. This can be conceptualized as the link or bridge between micro-level individual change in attitudes and macro-level or societal change.

Like stakeholders, focus group participants highlighted far fewer opportunities than obstacles, and also noted a number of structural-level opportunities such as government and international agency initiatives. Focus group participants also emphasized the importance of education - noting the role of the school curriculum as well as the significance of the teacher's role and that of the family. Also noted was the possible positive effect of moderate clergymen, and rights-awareness sessions and workshops for women.

\subsection{Strategies/initiatives}

Stakeholders commented on a wide range of examples of strategies and initiatives, related to women's empowerment programmes, working with youth and training officials. More training and empowerment programmes are needed, but the implementation and focus of existing programmes was often critiqued. Stakeholders asserted that the optimal approach for international agencies entails taking account of the local context and partnering with local actors, so as to promote a better understanding of the culture. The issue most often raised with current international agency strategies was that, 'They come and start work on a project with other organizations and institutions; after a time they don't continue or follow up. They come and implement a two-year programme and then leave, that's it. What can be done in two years?' This resonates with the idea that social change takes time, and that this should be recognized in the planning and organization of the work of international agencies. Another issue raised was the perception of wasting much-needed funds on superfluous administrative expenses and 'five-star' logistics.

Stakeholders also noted that one strategy which has shown success is making alliances with and promoting moderate clergy partners, as a means to counter misogynistic religious discourse. In addition, increasing secularization of politics and education, especially in school curriculum development, was seen as an important step. The importance of incorporating gender neutrality into curricula was also often discussed. It was also noted that there needs to be a roll-out of gender equality training for government, police and legal officials, as well as teachers and women leaders, indicating a perceived success of such initiatives on changing organizational culture and interpersonal dynamics in the workplace and community. 
Focus group participants were enthusiastic in their suggestions of possible improvements, and commented on a few examples of successful strategies and initiatives. There was very low awareness of initiatives for women in KRI besides the government offices and women's shelters, or distant knowledge of empowerment programmes. Most notably the quota was perceived to be good as a temporary measure; however, participants would like to see women succeed on their own terms. Additionally, the media was perceived as having a primary role to play in highlighting problems and promoting awareness: 'For example, before, we didn't know about the issue that would happen in courts, but only what was happening in our family and neighbourhood, there were no statistics.' Television is a possible means for affecting public awareness, especially in relation to GBV. One outspoken television presenter had a show about women's issues, but it was seen as bringing in foreign ideology and corrupting women's morality, so her show was discontinued.

\section{Positive examples}

Successes in KRI, as perceived by stakeholders, were mostly limited to government initiatives, which may have been due to the large proportion of government actors among the sample. Stakeholders noted that women in KRI are now able to pass their nationalities to their children, unlike in Lebanon and Jordan. This had been one of the reservations to CEDAW, but the central Iraqi government has recently removed this reservation. Within KRI, part of the 10-year government strategy is ending FGM, and the High Council is compiling new statistics on the prevalence of FGM, as currently held statistics are deemed to be inaccurate. Another government-related success was perceived to be the Ministry of Education's responsiveness in introducing changes in the school curriculum.

\section{Lessons learned}

Women's programmes need certain attention to be included in the national or international agency budgets, especially given competing priorities: 'With all the money going for refugee programmes we can no longer finance the project that gives free legal representation to Kurdish women.' In addition, many economic empowerment programmes for women inside the camps are unsuccessful: 'The problem is when international organizations come in with the easiest project, [for example] a sewing factory for women. There's no management and calculations of the expenses and the profit.' This type of criticism identifying issues relating to a lack of awareness of local needs, insufficient background research and inefficient implementation was often levelled at UN agency programmes.

Focus group participants found the prevalent sewing- and cooking-related women's empowerment programmes unsuccessful: 'Can she even open a sewing business? Will her husband let her, or let her keep the money?' Another initiative perceived as unsuccessful was that of the Ministry of Interior's DCVAW and the government-run women's shelters. Concerns about violence and exploitation by those in authority were rife: 'Her seeking refuge in such places results in violence against her twice.' In addition, a protest against GBV allegedly took place but 'was forgotten in two weeks'.

The term 'gender' was also mentioned as problematic in awareness campaigns and trainings; it tended to be confounded by a perception that it was in some way related to homosexuality. It was perceived that there had been no advances whatsoever on the LGBTQI front: 'If you talk about that here, they're gonna kill you.'

The government shelters, criticized by many stakeholders and focus group participants, were seen as unable to provide adequate security or facilities for vulnerable women. A range of reasons were cited for this, including insufficient budgets, lack of awareness among employees and the public, and inefficient judicial systems or systems within the shelters themselves.

Stakeholders suggested that a better understanding of women's issues in KRI could be gleaned from local and governmental statistics rather than those from UN agencies. They also saw a need to strengthen the bonds between government, civil society actors and international agencies in the form of agreements and workshops. Workshops were seen by most stakeholders as integral to these efforts, and suggestions included the request for international agencies to organize training sessions for government employees at 
all levels: 'The international NGOs don't work systematically in solving some problems. We need trainings to activate thought and create awareness.' In terms of increasing women's economic participation, several stakeholders suggested providing reliable and affordable childcare to enable women to join the workforce. In relation to political participation, due to the importance of political parties in KRI, stakeholders advocated the necessity of working with political parties to strengthen women's positions within them, while others suggested educating women leaders by sending them to workshops abroad. Stakeholders' suggestions were largely related to the inefficiency of women's programmes, government and CSO initiatives, and a lack of coordination among stakeholders, rather than reflecting a need for public awareness or more of the same kind of work that is currently being conducted.

As with stakeholders, both women and men stressed the need for work on education and the school curriculum. Again, like the stakeholders, focus group participants expressed that NGOs and international agencies should not waste money and need to follow up on their programmes. More than one woman expressed sentiments such as, 'Please follow up on this research; don't just take our opinions on paper.'

The need for initiatives to expand from Erbil to rural areas was noted by both women and men. Females mentioned that international agencies should cooperate with local agencies, 'because international ones have the means, and the local ones know about local problems and how they should be solved'. Other suggestions from women on increasing participation included employment offices specifically for women. Women suggested improving women's social conditions by working on men's attitudes and values as well as challenging misogynistic religious discourse through building partnerships with relatively moderate religious authorities. Men suggested that different types of awareness sessions should be targeted to different types of women in different social contexts; for example, teaching Western ideas of women's empowerment to a woman in a rural village may get her in trouble or keep her out of the [awarenessraising] programme. Like the stakeholders, men focus group participants recommended awareness and training for government and police officials.

\section{Notable stakeholders}

The High Council for Women's Affairs was perceived to have authority as it is a government office, with a proposed 10-year strategy for women's development, yet it is low on funds. UNDP, UNICEF and UNHCR were often brought up by stakeholders, though not always in a positive light (a few highlighted their unreliable research). Women's Empowerment Organization (WEO) was named as an effective local association working within Ain Kawa district, and President Masoud Barzani of KRI was repeatedly named as being supportive of women's rights and advancement. While being outspoken about the issues, he is also seen as strategic in making concessions to religious leaders. Male focus group participants did not refer to or name any stakeholders, perhaps suggesting lack of awareness of the issues. Women from the focus groups, like the stakeholders, mentioned the High Council for Women's Affairs and the WEO. In addition, Malala Yousafzai was mentioned as an inspiring role model for girls. 


\section{F. Comparative comments}

This section draws together the findings from across the three countries, identifying similarities and differences.

\section{Participation}

What emerges as a similarity in terms of conceptualizing participation is the recognition that it pertains to both the public and private spheres. A relatively instrumental construction of the rationale of women's participation is evident especially in Jordan, as well as in Lebanon. This could be interpreted as the more 'palatable' form of women's participation as it is understood primarily in terms of amelioration of poverty and extra income for the family, rather than a substantive shift in conceptualizing women's role in society more holistically. This is potentially problematic, as sustainable change must be based on individual, familial and societal commitment to attitudes and values of equality, rather than based on what may be a temporary situation of need.

This argument also resonates with the finding of the perception across all three country sites that there is no meaningful political participation of women - even in Jordan and KRI where institutional quotas for women have been introduced. This links to conceptualizing social change holistically, where legal and institutional changes are perceived as necessary but not sufficient, and must be accompanied by individual, familial and societal attitudinal change.

On discussing perceptions of change over time in the different country sites, all three noted that certainly the issues of women's participation and leadership, gender equality and women's rights are more visible in public discourse, through more advocacy work and awareness-raising initiatives. In this sense, there has been social change where change is conceptualized as a long-term process; with contributing to a conducive environment for change perceived to be an important step in the process towards sustained change. Some references to positive societal achievements were made across the three country sites. Both stakeholders and focus group participants expressed frustration at what they perceived to be slow progress, especially voiced in Jordan. Some male focus group participants in Jordan attributed perceived negative societal effects, such as higher divorce rates, to women's increased public participation.

Gendered differences emerged across all three country sites with respect to perceptions of women's participation, with men referring to women's (perceived) emotional nature as a barrier to effective participation and, in particular, decision making. This was one of the most common themes referred to in the focus group discussions in Jordan, and to a certain extent in Erbil and the focus groups in South Lebanon.

These findings support the approach of the LANA initiative in focusing on individual and familial attitudinal change as a critical component of social change. Educational and awareness-raising (e.g. media) programmes will be an important means to enable women and men to critically reflect on their gendered assumptions of their roles in society, and also to reflect on conceptions of justice and equality and how these interrelate.

\section{Leadership}

Across the three country sites, there was relatively less focus in the discussions on leadership compared to participation. In particular in the focus groups, leadership was often perceived as an abstract concept outside of the realms of experience for many women. In Jordan and Erbil, there were references to political quotas for women as being important as measures to give women access to leadership positions, although many were frustrated that this did not represent a real commitment to gender equality, but rather was 'surface' or window-dressing. In Jordan, in particular, many women were aware of a perception that they as women were perceived to be 'emotional' and therefore unsuited to leadership and decision making. In addition, in all three countries, there were domains that were deemed unsuitable for women to act in as leaders (with education a notable exception), in particular if this entailed 'unsociable' working hours, given societal concerns about women's honour, shame and perceived sexual vulnerability. Males expressed a belief that women already enjoy gender equality and participation in society, and that leadership is not 
suitable for women given their perceived emotional nature; in addition, women's leadership was linked to conflict in the family and rising divorce rates.

\section{Gender equality}

Although the term 'gender' has had negative connotations across all three locations to varying degrees, there was unanimous support for the concept of 'gender equality' when discussed in the abstract using different language and with religious references to justice. Differences emerged between men and women and across locations when discussions probed further in terms of what gender equality entails in practical terms. In general, men believed that gender equality exists in society, although in Jordan men expressed the belief that women must seek the permission of their male relatives regarding most issues, for example, going to work and leaving the house; paradoxically, obstacles identified included the threat to women's physical safety, shame and loss of family honour by being unaccompanied in the public sphere. Men also expressed that gender equality has a different meaning in the local context (in comparison to the West), where justice trumps equality. This suggests a conception of different gender roles that can be deemed equal in the abstract, while not advocating the same rights. For example, men in Jordan did not think that women's lack of nationality rights (i.e. being unable to pass their nationality to their children) illustrated a lack of gender equality, rather that 'children belong to the father' so the father has the 'responsibility' of providing the children with citizenship.

In Lebanon, some stakeholders warned of the illusion of gender equality, articulating a concern that women's more liberal attire and greater visibility in the streets should not be equated with 'freedom'. In fact, it was argued that this merely reflects a patriarchal society's practice of the sexual objectification of women (as in the West), but without the equal rights in law and cultural practices. It was also noted that it is very important to take account of intersectionality with respect to gender equality, where interviewees stressed differences between rural and urban contexts and different parts of the country and social class (e.g. Beirut versus Saida and Nabatieh; Amman versus Zarqa), with one interviewee rhetorically asking: 'How can gender equality be an issue when people are living on less than one dollar a day?' For those working in the field of LGBTQI rights (in Jordan and Lebanon), it was perceived to be important to make strategic alliances in fighting for the rights of those who are excluded or marginalized in society.

\section{Social change}

All three country sites emphasized an integrated approach of structural, legal change as well as changing individual attitudes and beliefs within families and local communities. Men tended to take a more functionalist approach, proposing relatively minor changes and preserving the status quo, and supporting differentiated gender roles and differential gender socialization. The majority of views saw social change as something gradual and taking time, with the older generation commenting on having witnessed social change with respect to gender equality, largely citing educational achievements. In Jordan and KRI, where gender quotas have been institutionalized, the importance of changing individuals' perceptions was especially emphasized. In KRI, it was also noted that war and conflict brings about social change, with participants citing women's roles in combat. In contrast, in Lebanon there was a greater stress on the importance of structural and institutional mechanisms for the promotion of gender equality, given their relative lack. As has been noted across all three country sites, education, media and social media were frequently mentioned as opportunities or facilitators for social change. This supports a model of social change where education and media - while also being domains that can act to represent and transmit the state's aims and values - can operate as dynamic platforms for social transformation. In the case of education, the role of teachers and the pedagogic relationship are critical, in conjunction with the family. As such, it can be theorized that education acts as a link between the micro-level of personal attitudes and the macro-level of social change.

\section{Obstacles and opportunities}

Both women and men perceived that there are substantive obstacles to promoting gender equality and women's leadership and participation in their societies. All countries share common societal features of 
patriarchal practices embedded in laws and societal practices, differential gender socialization, concepts of 'shame' and 'honour' limiting women's mobility, poverty, and a lack of a strong conception of citizenship. Personal factors are seen as relatively more significant in Jordan and KRI compared to Lebanon, with the husband typically cited as a key obstacle, in addition to the fear of violence - both domestic and in the public sphere.

With regards to opportunities, interviewees across all three countries talked of the potential of education and media, while acknowledging that in their current forms they can also pose as obstacles. Political quotas and institutional mechanisms are seen as opportunities, but as temporary measures. Youth/new generation and moderate clergy were also cited as possible opportunities. Paradoxically, poverty, war and conflict were cited as opportunities, where for instrumental reasons women gain opportunities for greater participation and leadership. These findings link with the findings of the preceding section on social change, supporting a model of social change where personal-level change in attitudes and values is facilitated through education and awareness-raising, in order to provide a sustainable context for legal and policy changes introduced in Jordan and KRI, and to further create a climate for such macro-level change in Lebanon. The importance of education and awareness-raising is also critical in a promoting a conceptual shift from conceiving of women's participation and leadership in primarily instrumental economic terms, rather than a more stable conception based on notions of gender equality and social justice.

As a final note, it is often assumed that the Arab region exhibits a paucity of women's rights, typically attributed to religion - and mainly Islam. What emerges from the findings of this project reinforces both theoretical arguments as well as other empirical data, that religion per se is not perceived locally to be a significant obstacle. Rather, key societal obstacles relate to patriarchal culture and cultural/tribal traditions, found across both Muslim and Christian communities in the three countries. This does not mean that religion is insignificant, as dominant societal discourses on control of women utilize various religious interpretations to legitimize and frame such discourses, which are culturally difficult to argue against. Hence it is seen as a more prudent strategy, even for secularists, to work with moderate clergy in order to push forward with their work in the field of women's rights and promoting women's participation and leadership. 


\section{G. Conclusions}

The overall aim of this study was to conduct qualitative research in Lebanon, Jordan and KRI to explore the dynamics that lead from individual change in perceptions and attitudes on gender equality to wider social and political change. This was broken down into two specific objectives:

1. To conduct a comparative assessment of the role customary institutions play in maintaining gender inequality in Lebanon, Jordan and KRI.

2. To analyse the chain of changes in perceptions and attitudes on gender equality from the individual sphere to the social and political spheres, and from local to national level.

With regards to the first objective, this was approached in terms of three research sub-questions examining: i) the nature of women's participation and how this varies in relation to age, socio-economic status, religion, legal status, etc.; ii) perceived obstacles to participation; and iii) key stakeholders' views on gender equality and women's participation.

Both stakeholders and male and female focus group participants across the three countries perceived women's participation in society to be important in both the public and private spheres, with economic participation perceived to be particularly important. It was recognized that participation varied significantly according to women's age, marital status, religion, socio-economic background and legal status, illustrating the importance of taking an intersectionally nuanced approach in understanding and promoting women's participation and gender equality. Of note was that rationales for women's participation were broadly framed in instrumental terms by most men and women across the three country sites, rather than in terms of gender equality and women's rights. Stakeholders were more likely to provide a rationale for women's participation and leadership in society in terms of gender equality. There was relatively less consensus on women's leadership, with men especially in Jordan and South Lebanon expressing views of women's 'emotional nature' limiting such capacities. In addition, dissatisfaction is expressed regarding low levels of women's political participation, especially in Lebanon, but also in Jordan and KRI where, even with quotas in place, there is a perception that women do not actually hold autonomous decision making capacity or promote gender equality per se. These findings illustrate highly gendered constructions of male and female roles in society, based on essentialized understandings of what it means to be a 'man' or a 'woman'.

With regards to the second objective focusing on the chain of changes in perceptions and attitudes on gender equality from the individual to societal sphere, and from local to national level, this was approached in terms of eight research sub-questions, including: i) women and men's perceptions of current levels of participation (and how this varies in relation to age, socio-economic class, marital status, religion, legal status, etc.); ii) what influences views and how can these be changed?; iii) how can individual change lead to societal change and how can change at local level lead to national-level change; iv) what are the existing opportunities; v) how does change happen?; vi) what strategies have worked and why?; vii) other initiatives or lessons learned; and viii) recommendations for action.

It has been noted that the second objective of elucidating a theory of change is an ambitious one given the scope and scale of the research, within a timeframe of seven months. This research provides contextspecific data giving an insight into local women's and men's views on these issues, as well as the views of stakeholders. As such, it should be recognized that it is limited in fully elucidating a theory of change, but rather provides some suggestions for interesting lines of further inquiry. In particular, sub-questions iii) understanding how individual change transforms to societal-level change and moves from the local to the national, needs further focused work, and this is also the case for sub-question v) how does change happen (elucidating a theory of social change).

That said, some interesting observations can be made relating to this second objective. Regarding levels of women's participation (sub-question i), while most stakeholders on the whole perceived levels of participation to have improved, some stakeholders expressed a perception that they have declined over the last five years, and this was attributed to political instability, increased poverty and the 'Arab Spring'. On the other hand, stakeholders believed that there is a higher visibility and a greater level of advocacy and positive media coverage for issues of women's participation and leadership, gender equality and violence 
against women, compared to 10 years ago. Yet some frustration was expressed with regards to visibility not translating into quality women's participation. These perceived changes were attributed to changes at international policy levels (e.g. the Beijing +20 review and CEDAW were cited as important), and to a certain extent in regional and national policy levels. In general, focus group participants perceived that there had been improvement in terms of women's participation, although in Lebanon women's severe lack of representation in the political sphere was noted by both men and women, with formal politics seen as a masculine activity associated with war and violence. In Jordan and KRI, although women are visible in politics through quotas, frustration was expressed with regards to the quality and 'authenticity' of women's participation and leadership, especially in KRI.

In terms of what influences views on participation and gender equality (sub-question ii), a range of factors were identified and organized in terms of four levels: personal, societal, structural and strategic. A clear difference emerged between the perceptions of stakeholders and focus group participants, with stakeholders more likely to identify structural and strategic factors as obstacles (for example, laws or institutional access, childcare provision), compared to focus group participants' relative focus on personal and societal factors (for example, perceptions of husbands, notions of shame and honour, socialization into highly gendered roles, essentialized biological notions of masculinity and femininity, perceptions of physical and sexual vulnerability, and fear of violence). This may be partly due to stakeholders' NGO work focusing on legal and institutional structural issues, and their relatively elite positions in society where they may not face personal and societal obstacles to the same extent as the more disadvantaged women and men in the focus groups. It may also result from a lack of knowledge among women and men in focus groups with regards to more institutionalized obstacles to women's participation and gender equality.

Regarding the issue of understanding a theory of social change - moving from the individual to the societal level, and from the local to the national level - it was perceived in Lebanon and Jordan that women have a relatively greater presence in local politics through municipalities and, informally, through CSOs and initiatives. On comparing Jordan and Lebanon, Lebanon is much less successful with respect to women's presence in formal politics, yet there is greater visibility of women in demonstrations and protests, labour movements and local politics. The fact that participation in local politics does not translate into participation in national-level politics may be accounted for, in part, by Lebanon's patriarchal system, which was also perceived to account for women's lower levels of participation in the public sphere in general. Further research is recommended to elucidate the obstacles in moving from participation at a local level to a national level.

Regarding moving from the individual level to the societal level - in essence elucidating a theory of social change (sub-questions iii and v), some insight may be derived from the numerous comments on the importance of education and awareness-raising through media and social media. Education, media and social media were frequently mentioned across all three countries as opportunities or facilitators for social change. We propose that this supports a model of social change where education and media - while being domains that can act to represent and transmit the state's aims and values - can also be conceptualized to operate as a dynamic 'meso-level' domain for social transformation. Education - both formal and through the family - can play an important role in encouraging reflection on constructions of gender and expectations of gender roles in society. Teachers and the pedagogic relationship are vital, in conjunction with the family. As such, education plays a crucial role as a link between the micro-level of personal attitudes to the macro-level of social change - facilitating the chain of changes from the personal to the societal level.

Regarding existing opportunities for change (sub-question iv), education as a channel for socio-political transformation is recognized as critical. Again, education can be conceived of both as a structural-level opportunity, in that education is a channel through which the nation's objectives and values are transmitted, but it also has the potential to play a critical role in social change as a meso-level mechanism between personal- and family-level attitudes and values, and larger scale societal change.

Media, social media and advertising campaigns were also highlighted by both stakeholders and focus group participants, although focus group participants expressed some ambiguity/tension, with media 
perceived also to play a negative role. Similarly, media and social media, like education, reflect society's values and attitudes, as well as providing a space for social transformation. Stakeholders attributed media and social media with creating a more conducive climate for their work, given their role in increasing awareness of women's rights and interrelated issues (including child labour, trafficking, sexual health, migrant and refugee rights, LGBTQI rights), as well as greater awareness of human rights. Focus group participants insightfully noted the importance of involving men in initiatives, and saw potential in working with international NGOs. Only some men in the focus groups perceived religion to be empowering. In addition, in Lebanon in particular, the potential of civil society - and especially youth - was seen as an opportunity for social change. Religion was not frequently mentioned as an opportunity, and tended to be referred to only by some men in some of the focus groups across all three country sites.

With regards to perceived successful strategies (sub-questions vi and vii), some stakeholders noted awareness-raising campaigns - for example, the domestic violence awareness-raising campaign in Lebanon, as well as knowledge empowerment initiatives, e.g. ICT training for women refugees in Lebanon. These initiatives may have had an impact both through equipping women with skills as well as bringing about attitude change through exposure to new experiences. Another strategy referred to in both Lebanon and $\mathrm{KRI}$ was working with moderate clergy as a means to counter misogynistic religious discourse. Stakeholders and focus group participants both stressed the importance of international organizations understanding the local context, giving initiatives sufficient time to embed, and following them up. In addition, coordination between the different stakeholders was perceived to be important in achieving successful outcomes.

\section{H. Recommendations}

In this final section, a number of tentative recommendations drawn from the stakeholder interviews and focus group discussions have been identified and formulated in relation to the obstacles and opportunities identified in the previous sections. It should be reiterated that given the scale and scope of the research, more work needs to be done to further examine the interrelationships between structures and societal institutions and personal and socio-cultural attitudes and values, in particular in relation to elucidating further the second objective of the study, i.e. analysing the chain of social change. The recommendations have been organized in terms of the level of intervention (personal, societal, structural, strategic), and are largely addressed to NGOs, both local and international. Recommendations relating to quotas and education are addressed to NGOs campaigning in these domains as well as governments.

\section{Personal/societal}

Economic empowerment initiatives for women (including micro-loans): As economic participation has been identified as a priority, and given the context of poverty and political uncertainty, we recommend a particular focus on promoting women's access to the labour market through a range of initiatives including practical skills training (e.g. ICT, language) and supporting women starting small businesses (e.g. business entrepreneurship training and advertisement/facilitation of access to micro-loan schemes). This will also require structural accommodations relating to childcare provision - ideally low-cost or free, to be provided by employers. It is important that rationales for such initiatives are not solely predicated on poverty alleviation however, but rather are premised on gender equality in order to achieve sustained change.

Increased funding for projects working on ending violence against women: This is critically important both in terms of values of human dignity and gender equality, but also instrumentally in terms of creating a safe environment so that women feel safe in the public sphere, as well as combating violence in the private sphere. Women's participation and leadership is directly linked to levels of violence and perceived levels of violence against women, publically and privately.

Dialogue with partners - moderately religious clergy: The interpretation of religious discourse has been identified as an obstacle in promoting gender equality, and so it is important to work cooperatively with moderately religious stakeholders who have significant influence within local communities. This links with the role of education and awareness-raising in a chain of social change. 
Including men in gender equality initiatives: It is important that promoting gender equality is understood to be in the interests of society as a whole, as opposed to men's versus women's interests, and that misconceptions (e.g. perceived threats to men's employment or standing in society by the promotion of women's rights and participation) are challenged. Such initiatives will need to go beyond paying lip service to gender equality in the abstract, but rather will have to engage substantively with the implications for people in their daily lives of promoting gender equality and women's participation and leadership.

\section{Structural}

Campaigning for legal and policy changes: Changes to policies and laws can be conceptualized as necessary but not sufficient in and of themselves, rather they must be in conjunction with critically important work at the grassroots level on attitude change. This recommendation recognizes the interdependence between macro and micro levels in promoting social change. This was particularly stressed in the Lebanese context in relation to women's political participation and nationality rights. In Jordan and KRI, a relatively greater emphasis was placed on changing attitudes at the personal, family and tribal levels. These relative emphases can be interpreted in relation to the introduction of legal and policy changes in KRI and Jordan, in contrast to Lebanon.

Quotas as intermediary measures to promote women's participation and leadership to be coupled with substantively prioritizing and promoting gender equality institutionally (e.g. a watchdog in Cabinet looking out for women's issues in all areas of decision making, including budgeting). Greatest scepticism about quotas was expressed in Lebanon, where they do not exist and where there is a perception that quotas are not a political possibility, given that campaigners on this issue have had relatively little success to date. There is a counter-discourse that women-only quotas are 'discriminatory', which is paradoxical given that the political governance system is fundamentally organized around the use of quotas to distribute power proportionally among different religious groups. In addition, in KRI there was a dominant perception that the quota did not reflect a substantive commitment to gender equality, nor did it bring about positive change, given the idea that women promoted to these positions were 'proxies' for males of certain dominant families and could not autonomously take decisions. Also it was felt that these women were not necessarily committed to gender equality and women's participation and leadership. Nevertheless, at a minimum, quotas promote the visibility of women in the public sphere and 'normalize' their presence as participants and leaders of society.

Inclusive and supportive gender-sensitive policies and networks: Recommendations include building and institutionalizing women's professional support networks, given the relative lack of these, in order to provide institutionalized forums for sharing experiences and good practice as well as moral support. In addition, inclusive policies for women in political parties will enable women's political participation at the national level.

Educational reform: Given the critical potential of education in the promotion of gender equality, it is recommended that curricular reform is implemented to remove gender stereotypes and to represent women in positive role models. In addition, the systematized introduction of gender-sensitive teachertraining is recommended both to promote pedagogical practice and also to improve workplace conditions for women teachers.

Youth initiatives: Related to and extending the recommendation on educational reform, it is important to maximize the significant potential of youth in the three countries, given their large demographic presence. In Lebanon in particular, youth have shown significant dynamism in campaigning for social change, as witnessed in the ongoing trash protests, where young women also have played a substantive leadership role. Recommendations entail prioritizing funding for youth training projects, e.g. developing skills in campaigning, media and civic literacy, organizing and leading projects, etc.

\section{Strategic}

More coordination between NGOs and between local and international initiatives/organizations: It was widely recognized that there is a lack of coordination for various reasons, including perceived competition 
for funding, which is divisive and against the strategic interests of the organizations. Coordination should be institutionalized in the form of coalitions to overcome these obstacles.

Media and digital media campaigns (e.g. against sexist advertisements), as well as gender-sensitive programming: The influence of the media - both potentially positive as well as negative - was widely recognized. Campaigns are needed against gendered stereotypes and the sexual objectification of women in the media, as well as the promotion of a gender-sensitive environment for women participating and in leadership positions in the media industry.

Coordinating with broader campaigns for marginalized groups linked to a conception of inclusive citizenship (migrant worker rights, refugee rights, LGBTQI rights as well as women's rights): Campaigns for equal rights across different marginalized groups should coordinate to consolidate strategic efforts. Not only is this strategic/instrumental, but it reflects a conceptual and principled understanding of inclusive citizenship - for women and other marginalized groups in society. This will require a conceptual shift, as it is not widely occurring in the three countries. Particularly marginalized groups, namely LGBTQI and migrant workers (in Lebanon and Jordan) recognize the potential of such coordination with groups campaigning for and working on women's rights issues, although it is reported that women's rights groups are not always open to working with LGBTQI groups in particular, given negative attitudes to non-normative sexuality.

Promoting democratic citizenship/ending sectarianism: The promotion of gender equality and institutionalization of laws and policies in the public sphere is predicated on a social contractual understanding of the relationship between citizens and their state. As such, many commented on how all people, not just women, are 'not really citizens' first and foremost but members of families, tribes or sects. As such, promoting a civil democratic citizenship and renegotiating a new social contract, as has been unfolding across the Arab region, is an important part of this social change. 
I. References

Basu, A. (1995). The Challenge of Local Feminisms: Women's Movements in Global Perspective. Boulder: Westview Press.

Faour, M. A. (2007). 'Religion, demography, and politics in Lebanon', Middle Eastern Studies, 43(6), 909-921.

Foucault, M. (1998). The History of Sexuality: The Will to Knowledge. London: Penguin.

Giddens, A. and Sutton, P. W. (2014). Sociology. ( $7^{\text {th }}$ edition). Cambridge and Malden, MA: Polity Press.

Haider (2011). 'An Investigation into the Meaning of Locally Produced Entertainment Media to Lebanese Women: A Concentration on the Film Sukkar Banat (Caramel)'. Media@LSE Electronic MSc Dissertation Series. http://www.Ise.ac.uk/collections/media@Ise/mediaWorkingPapers/

Hall, S. (1997). Representation: Cultural representations and signifying practices. London: Sage.

Happer, C. and Philo, G. (2013). The role of the media in the construction of public belief and social change. Journal of Social and Political Psychology, 1, 321-336.

HRW (2003). Human Rights Watch Briefing Paper

Background on Women's Status in Iraq Prior to the Fall of the Saddam Hussein Government November, 2003. Accessed 12 September 2015 at: http://www.hrw.org/legacy/backgrounder/wrd/iraqwomen.htm

Kharroub, T. and Weaver, A. J. (2014). 'Portrayals of women in transnational Arab television drama series', Journal of Broadcasting and electronic media, 58 (2), 197-195.

Kiwan, D. (2008). Education for Inclusive Citizenship. London and New York: Routledge.

Kiwan, D. (eds). (2013). Naturalisation policies, education and citizenship: multicultural and multination societies in international perspective. London and New York: Palgrave Macmillan.

Lauzen, M. M., Dozier, D. M. and Hicks, M. V. (2001). 'Prime-time players and powerful prose: the role of women in the 1997-1998 television season', Mass Communication and Society, 4 (1), 39-59.

Oxfam (2014a). OXFAM GB - Invitation to Tender for Women's Participation and Leadership in Jordan, Lebanon and Iraq: Moving from Individual to Collective Change.

Oxfam (2014b). LANA: Transformative Political Identities for Gender Equality in Jordan, Iraq and Lebanon: Project Proposal (Appendix C).

Pykett, J. (2010). 'Citizenship education and narratives of pedagogy', Citizenship Studies, 14 (6), 621-635.

Rabinow, P. (ed). (1991). The Foucault Reader: An introduction to Foucault's thought. London: Penguin.

Sieder, R. and McNeish, J. 2013. Gender justice and legal pluralities. Latin American and African perspectives. New York: Routledge-Cavendish.

Gerding, A. and Signorielli, N. (2012). 'Gender roles in Tween television programming: a content analysis of two genres', Sex Roles, 70, 43-56.

Parsons, T. (1966). Societies: Evolutionary and comparative perspectives. Englewood Cliffs, NJ: Prentice Hall. UN Women (2012): Progress of the World's Women: In Pursuit of Justice: 124.

UNDP (2013) Gender Inequality Index available at https://data.undp.org/dataset/Table-4-Gender-InequalityIndex/pq34-nwq

UNESCO (2014). UNESCO's Promise Gender Equality: A Global Priority. Paris, France: UNESCO.

UNESCO (2015). Global Citizenship Education.: topics and learning objectives. Paris, France: UNESCO.

UNESCO (2015b). A Guide for Gender Equality in Teacher Education Policy and Practices. Paris, France: UNESCO.

UNHCR (2014a). 2014 Syria Regional Response Plan: Strategic overview. Accessed 31 January 2014 at:

http://www.unhcr.org/syriarrp6/docs/Syria-rrp6-full-report.pdf 
UNHCR, (2015). 2015 UNHCR country operations profile - Jordan. Accessed 11 September 2015 at: http://www.unhcr.org/pages/49e486566.html.

UNICEF (2011). Iraq MENA Gender Equality Profile. Accessed 11 September 2015 at:

http://www.unicef.org/gender/files/Iraq-Gender-Eqaulity-Profile-2011.pdf

UNRWA (2013a). In Figures. Accessed 31 January 2014 at:

http://www.unrwa.org/sites/default/files/2013042435340.pdf

Walby S., Armstrong, J. and Strid, S. (2012). 'Intersectionality: Multiple Inequalities in Social Theory', Sociology, $46(2), 224-240$.

World Economic Forum. (2014). The Global Gender Gap Report. Accessed 16 September 2015 at:

http://www.weforum.org/reports/global-gender-gap-report-2014 


\section{J. Appendices}

Appendix 1: Tables of comparative gender statistics by country

Lebanon (Global Gender Gap Report 2014)

\begin{tabular}{|l|l|l|l|}
\hline $\begin{array}{l}\text { Economic } \\
\text { participation } \\
\text { (ranked: 133) }\end{array}$ & Rank & $\begin{array}{l}\text { Score } \\
\text { (0=no equality; 1=equality) }\end{array}$ & Female-male ratio \\
\hline $\begin{array}{l}\text { Labour-force } \\
\text { participation }\end{array}$ & 135 & 0.34 & 0.34 \\
\hline Wage equality & 104 & 0.58 & 0.58 \\
\hline Senior managers & 118 & 0.09 & 0.09 \\
\hline
\end{tabular}

\begin{tabular}{|l|l|l|l|}
\hline $\begin{array}{l}\text { Educational participation } \\
\text { (ranked: } 106)\end{array}$ & Rank & $\begin{array}{l}\text { Score } \\
\text { (0=no equality; } \\
\mathbf{1}=\text { equality) }\end{array}$ & Female-male ratio \\
\hline Literacy rate & 103 & 0.92 & 0.92 \\
\hline Enrolment in primary & 128 & 0.93 & 0.93 \\
\hline Enrolment in secondary & 1 & 1 & 1 \\
\hline Enrolment in tertiary & 1 & 1 & 1 \\
\hline
\end{tabular}

\begin{tabular}{|c|c|c|c|}
\hline $\begin{array}{l}\text { Political leadership } \\
\text { (ranked: 141) }\end{array}$ & Rank & $\begin{array}{l}\text { Score } \\
\text { ( } 0=\text { =no equality; } \\
1=\text { equality) }\end{array}$ & Female-male ratio \\
\hline Women in Parliament & 131 & 0.03 & 0.03 \\
\hline $\begin{array}{l}\text { Women in ministerial } \\
\text { positions }\end{array}$ & 138 & 0 & 0 \\
\hline $\begin{array}{l}\text { Years with female head } \\
\text { of state (last 50) }\end{array}$ & 64 & 0 & 0 \\
\hline
\end{tabular}


Jordan (Global Gender Gap Report 2014)

\begin{tabular}{|l|l|l|l|}
\hline $\begin{array}{l}\text { Economic } \\
\text { participation } \\
\text { (ranked: } 140)\end{array}$ & Rank & $\begin{array}{l}\text { Score } \\
(\mathbf{0}=\text { no equality; 1=equality) }\end{array}$ & Female-male ratio \\
\hline $\begin{array}{l}\text { Labour-force } \\
\text { participation }\end{array}$ & 139 & 0.23 & 0.23 \\
\hline Wage equality & 74 & 0.63 & 0.63 \\
\hline Senior managers & 119 & 0.09 & 0.09 \\
\hline
\end{tabular}

\begin{tabular}{|l|l|l|l|}
\hline $\begin{array}{l}\text { Educational participation } \\
\text { (ranked: 74) }\end{array}$ & Rank & $\begin{array}{l}\text { Score } \\
\text { (0=no equality; } \\
1=\text { equality) }\end{array}$ & Female-male ratio \\
\hline Literacy rate & 69 & 0.99 & 0.99 \\
\hline Enrolment in primary & 104 & 0.98 & 0.98 \\
\hline Enrolment in secondary & 1 & 1 & 1.03 \\
\hline Enrolment in tertiary & 1 & 1 & 1.15 \\
\hline
\end{tabular}

\begin{tabular}{|l|l|l|l|}
\hline $\begin{array}{l}\text { Political leadership } \\
\text { (ranked: 119) }\end{array}$ & Rank & $\begin{array}{l}\text { Score } \\
\text { (0=no equality; } \\
1=\text { equality) }\end{array}$ & Female-male ratio \\
\hline Women in Parliament & 107 & 0.14 & 0.14 \\
\hline $\begin{array}{l}\text { Women in ministerial } \\
\text { positions }\end{array}$ & 98 & 0.13 & 0.13 \\
\hline $\begin{array}{l}\text { Years with female head } \\
\text { of state (last 50) }\end{array}$ & 64 & 0 & 0 \\
\hline
\end{tabular}


Iraq (UNICEF, 2011)

\begin{tabular}{|l|l|}
\hline Economic participation & \% females enrolled \\
\hline Women 15-24 & 8 \\
\hline Women 15+ & 14 \\
\hline
\end{tabular}

\begin{tabular}{|l|l|}
\hline Educational participation & \% females enrolled \\
\hline Youth literacy & 80 (81.6\% for women in Kurdistan) \\
\hline Primary & 82 \\
\hline Secondary & 38 \\
\hline
\end{tabular}

\begin{tabular}{|l|l|}
\hline Political leadership & $\%$ women \\
\hline Women in Parliament & $25 \%(30 \%$ in KRG - Erbil) \\
\hline Women in ministerial positions & 1 (out of 26 in KRG - Erbil) $^{34}$ \\
\hline
\end{tabular}

${ }^{34}$ Kurdish Regional Government, accessed 11 September 2015 at: http://cabinet.gov.krd/p/p.aspx?I=12\&p=229 
Other measures of gender equality in comparative perspective: ${ }^{35}$

\begin{tabular}{|l|l|l|l|}
\hline \multicolumn{2}{|l|}{ Table 1: Women's participation in decision making processes } \\
\hline & Iraq & Jordan & Lebanon \\
\hline Right to vote & 1980 & 1974 & 1952 \\
\hline Right to stand for election & 1980 & 1974 & 1952 \\
\hline $\begin{array}{l}\text { Women's representation in } \\
\text { National Parliament }\end{array}$ & $25.2 \%$ & $11.1 \%$ & $3.1 \%$ \\
\hline $\begin{array}{l}\text { Women's share of } \\
\text { ministerial positions }\end{array}$ & $10 \%$ & $7 \%$ & $7 \%$ \\
\hline $\begin{array}{l}\text { Constitutional quota for } \\
\text { national Parliaments }\end{array}$ & YES & YES & NO \\
\hline
\end{tabular}

\begin{tabular}{|c|c|c|c|}
\hline & Iraq & Jordan & Lebanon \\
\hline $\begin{array}{l}\text { Gender inequality } \\
\text { index ranking }\end{array}$ & 120 & 99 & 78 \\
\hline $\begin{array}{l}\text { Women can pass } \\
\text { citizenship to children }\end{array}$ & YES & NO & NO \\
\hline $\begin{array}{l}\text { Education, at least } \\
\text { secondary }\end{array}$ & $\begin{array}{l}22 \% \text { women } \\
42.7 \% \text { men }\end{array}$ & $\begin{array}{l}68.9 \% \text { women } \\
77.7 \% \text { men }\end{array}$ & $\begin{array}{l}53 \% \text { women } \\
55.4 \% \text { men }\end{array}$ \\
\hline $\begin{array}{l}\text { Labour-force } \\
\text { participation }\end{array}$ & $\begin{array}{l}14.5 \% \text { women } \\
69.3 \% \text { men }\end{array}$ & $\begin{array}{l}15.6 \% \text { women } \\
65.9 \% \text { men }\end{array}$ & $\begin{array}{l}22.6 \% \text { women, } \\
70.8 \% \text { men }\end{array}$ \\
\hline
\end{tabular}

${ }^{35}$ UN Women, 2012; UNDP, 2013. 


\section{Appendix 2: Reservations to CEDAW}

Jordan does not consider itself bound by the following provisions:

1. Article 9, paragraph 2 (States Parties shall grant women equal rights with men with respect to the nationality of their children);

2. Article 15, paragraph 4 (a wife's residence is with her husband) (States Parties shall accord to men and women the same rights with regard to the law relating to the movement of persons and the freedom to choose their residence and domicile);

3. Article 16, paragraph (1) (c), relating to the rights arising upon the dissolution of marriage with regard to maintenance and compensation (The same rights and responsibilities during marriage and at its dissolution);

4. Article 16, paragraph (1) (d) (The same rights and responsibilities as parents, irrespective of their marital status, in matters relating to their children; in all cases the interests of the children shall be paramount);

and (g) (The same personal rights as husband and wife, including the right to choose a family name, a profession and an occupation).

Lebanon's reservations:

The Government of the Lebanese Republic enters reservations regarding article 9 (2), (States Parties shall grant women equal rights with men with respect to the nationality of their children);

and article 16 (1) (c) (d) (f) and (g) The same rights and responsibilities during marriage and at its dissolution;

(d) The same rights and responsibilities as parents, irrespective of their marital status, in matters relating to their children; in all cases the interests of the children shall be paramount; f) The same rights and responsibilities with regard to guardianship, wardship, trusteeship and adoption of children, or similar institutions where these concepts exist in national legislation; in all cases the interests of the children shall be paramount;

(g) The same personal rights as husband and wife, including the right to choose a family name, a profession and an occupation (regarding the right to choose a family name).

In accordance with paragraph 2 of article 29, the Government of the Lebanese Republic declares that it does not consider itself bound by the provisions of paragraph 1 of that article.

Iraq's reservations:

1. Approval of and accession to this Convention shall not mean that the Republic of Iraq is bound by the provisions of article 2, paragraphs ( $\mathrm{f}$ ) and $(\mathrm{g})$ :

f) To take all appropriate measures, including legislation, to modify or abolish existing laws, regulations, customs and practices which constitute discrimination against women;

g) To repeal all national penal provisions which constitute discrimination against women.

of article 9, paragraphs 1 and 2:

Article 9

1. States Parties shall grant women equal rights with men to acquire, change or retain their nationality. They shall ensure in particular that neither marriage to an alien nor change of nationality by the husband during marriage shall automatically change the nationality of the wife, render her stateless or force upon her the nationality of the husband.

2. States Parties shall grant women equal rights with men with respect to the nationality of their children.

nor of article 16 of the Convention. 
1. States Parties shall take all appropriate measures to eliminate discrimination against women in all matters relating to marriage and family relations and in particular shall ensure, on a basis of equality of men and women:

a) The same right to enter into marriage;

b) The same right freely to choose a spouse and to enter into marriage only with their free and full consent;

c) The same rights and responsibilities during marriage and at its dissolution;

d) The same rights and responsibilities as parents, irrespective of their marital status, in matters relating to their children; in all cases the interests of the children shall be paramount;

e) The same rights to decide freely and responsibly on the number and spacing of their children and to have access to the information, education and means to enable them to exercise these rights;

f) The same rights and responsibilities with regard to guardianship, wardship, trusteeship and adoption of children, or similar institutions where these concepts exist in national legislation; in all cases the interests of the children shall be paramount;

g) The same personal rights as husband and wife, including the right to choose a family name, a profession and an occupation;

h) The same rights for both spouses in respect of the ownership, acquisition, management, administration, enjoyment and disposition of property, whether free of charge or for a valuable consideration.

2. The betrothal and the marriage of a child shall have no legal effect, and all necessary action, including legislation, shall be taken to specify a minimum age for marriage and to make the registration of marriages in an official registry compulsory. The reservation to this last-mentioned article shall be without prejudice to the provisions of the Islamic Shariah according women rights equivalent to the rights of their spouses so as to ensure a just balance between them. Iraq also enters a reservation to article 29, paragraph 1 , of this Convention with regard to the principle of international arbitration in connection with the interpretation or application of this Convention.

\section{Appendix 3: List of Stakeholders and focus groups by country/region}

\section{Lebanon}

\section{Stakeholders}

\section{Beirut}

1. Economic and Social Commission for Western Asia (ESCWA)

2. Senior female administrator and academic - American University of Beirut (AUB)

3. HELEM (Lebanese Protection for Lesbians, Gays, Bisexuals and Transgenders) representative

4. The Lebanese Council to Resist Violence Against Women (LECORVAW) representative

5. Kohl representative

6. Joumanna Haddad - Annahar

7. Caritas representative

8. ABAAD (Resource Centre for Gender Equality) representative

9. Institute for Women's Studies in the Arab World (IWSAW) representative

10. Women in Front (WIF) representative

11. League of Lebanese Women in Business (LLWB) representatives

12. Dar Al Amal representative

13. Shari'a Judge and Expert

14. Nadine Moussa - Female presidential candidate

15. Basma and Zeitouna (Sabra camp) 
16. Samy Gemayel - Kataeb MP

17. Regional Gender Advisor - OHCHR

18. National Commission for Lebanese Women (NCLW)

19. Meem/Nasawiya - former representative and activist

20. Palestinian Arab Women's League (PAWL) (interview not recorded)

21. Ministry of Education gender committee member (interview not recorded)

22. Saida

23. Development for People and Nature Association (DPNA)

24. Administrator - Law School at Lebanese University

25. Activist and Saida NGO member

26. Nabatieh

27. Lawyer in Political Party

\section{Focus groups}

\section{Beirut}

1. Female students from the AUB Gender and Sexuality Club

2. Females working in advertising and marketing (in their 20s)

3. Female migrant workers (mostly Ethiopian)

4. Male mosque frequenters (youth)

5. Male university students with interest in gender

6. Males working in advertising and marketing (20s-30s)

\section{Mt Lebanon}

1. Female beneficiaries of Caritas

2. Females from the mosque in Dahieh

3. Female Palestinian refugees from Dbayeh

4. Male Palestinian refugees from Dbayeh

5. Male Arab university students, Middle East University(MEU)

6. Male Kataeb members youth

\section{Saida}

1. Female civil society and government employees

2. Female Lebanese University (LU) students

3. Male civil society representative and priest

4. Male civil society representative and municipality board member

5. Male LU students

\section{Nabatieh}

1. Female NGO Employees

2. Female Ministry of Social Affairs employees

3. Female Syrian refugees

4. Male Ministry of Social Affairs employees

5. Males from local mosque

6. Males civil society representatives and businessmen 


\section{Jordan}

\section{Stakeholders (only Amman)}

1. Ministry of Education representative

2. Rana Husseini - Reporter on honour crimes

3. Academic - the Center for Women's Studies (WSC) at University of Jordan

4. Princess Basma Foundation

5. Jordanian Women's Union (JWU)

6. The Jordanian Hashemite Fund for Human Development (JOHUD)

7. Asma Khader - Sisterhood is Global Institute (SIGI) and former minister

8. LGBTQI activist

9. United Nations Relief and Works Agency (UNRWA)

10. Queen Rania Foundation

\section{Focus groups}

\section{Amman}

1. Female cultural centre employees in East Amman

2. Females at the Jordanian Women's Union

3. Female beneficiaries of Princess Basma Foundation

4. Female youth volunteers at Loyac West Amman

5. Female graduate students at WSC in University of Jordan

6. Male cultural centre employees in East Amman

7. Male youth volunteers at Loyac West Amman

\section{Zarqa}

1. Females in Zarqa camp (young graduates)

2. Females at the Jordanian Women's Union

3. Male students at the Hashemite University

4. Male students at the Hashemite University

5. Males in Zarqa camp.

\section{KRI - Erbil}

\section{Stakeholders}

1. Kurdistani Ministry of Education representative

2. Ministry of Labour and Social Affairs-KRI representative

3. Higher education consultant to Prime Minister

4. Minister of Higher Education and Scientific Research - KRI

5. Manager in KRI Ministry of Education

6. Women's Empowerment Organization (WEO) representative

7. Refugee Council in Erbil representative

8. Independent commission for human rights in KRI, Journalist

9. Department to Combat Violence Against Women, Ministry of Interior-KRI representative

10. High council for women's affairs in KRI

11. United Nations Development Programme (UNDP) representative

12. People's Aid Organization 


\section{Focus groups}

1. Females at Kurdistan Women's Union

2. Females at Public Aid Organization (PAO)

3. Females at USAID

4. Females in Ain Kawa

5. Males at PAO

6. Males at USAID

7. Males in Ain Kawa

Table showing breakdown by gender at each of the sites of data collection across the three countries

\begin{tabular}{|l|l|l|l|}
\hline Location & Female focus groups & Male focus groups & Total focus groups \\
\hline Lebanon - Beirut & 3 & 3 & 6 \\
\hline Lebanon - Mt Lebanon & 3 & 3 & 6 \\
\hline Lebanon - Saida & 3 & 3 & 6 \\
\hline Lebanon - Nabatieh & 3 & 3 & 6 \\
\hline Lebanon total & 12 & 12 & 24 \\
\hline Jordan - Amman & 4 & 2 & 6 \\
\hline Jordan - Zarqaa & 2 & 3 & 5 \\
\hline Jordan total & 6 & 5 & 11 \\
\hline KRI & 4 & 3 & 7 \\
\hline Whole sample total & 22 & 20 & 42 \\
\hline
\end{tabular}

\section{Appendix 4: Schedule of questions for stakeholders}

(NB: distinguish between individual's position and position of organization if applicable)

1. Introductions

i) What is the nature of your involvement/work in this field of women's participation and leadership? (Explore how long they have been working in the field, type of experience)

ii) How did you become interested and involved in this work?

iii) Why is this important to you?

iv) In your view, how have the issues of women's participation and leadership, gender equality and women's rights evolved in your work?

2. Conceptual understandings of women's 'participation' and 'leadership'

i) What does this mean to you? (explore first conceptions of participation and then of leadership)

ii) What does it cover?/What should it cover? (exploring perceived scope of the field)

iii) What does being a member of society/being a citizen mean to you? (explore, for example, whether there is a greater focus on legal status, rights, moral framing, participation, identity, etc.) 
iv) How does this relate to womens' role in society? Women's participation and leadership ? Gender equality?

v) What does it mean to talk about women's leadership and participation in refugee populations? (explore attitudes to participation and leadership for those with different legal/citizenship status e.g. refugees)

3. Current situation:

i) According to you, what are the current levels of women's participation in the public and private sphere? And similarly, for leadership?

ii) What do you think about current levels of women's participation?

iii) What do you think about current levels of women's leadership?

iv) Explore this in different domains for both participation and leadership, e.g. education, employment, politics, culture.

v) In your view, who are the main actors in the domain of women's leadership and participation? How would you characterize the women who currently participate and lead in your community? What are the barriers to such participation and leadership/who gets excluded? Do you think there is enough focus on ordinary women? (prompt for how this might vary by socio-economic class, religion, age, citizenship-status)

4. What is gender equality in practice?

i) What does gender equality mean to you? How do you understand this in terms of gender norms and roles in society? In relation to women's rights?

ii) What are the main influences of these norms and roles?

iii) Should these be challenged?

iv) How should they be challenged?

v) What does this mean to you on a personal level in terms of your own work?/involvement in this field? (prompt participants for actual examples)

5. Exploring possibilities for change:

i) From your own experience, what can be done that would lead to greater participation and leadership by women in society?

ii) How and/or does this relate to gender equality? Women's rights?

iii) Who are the actors bringing about change?

iv) Can you characterize how you carry out your work? Who are the different actors you work with?

v) What in your view are the greatest challenges? (prompt participants to explore e.g. people's opinions, practices, culture, tradition, institutions e.g. education, media, foreign intervention, conflict etc; prompt to give actual examples)

vi) What in your view are the possible opportunities that can lead to change? (e.g. could prompt discussion on ongoing revolutions and change in the Arab world, role of NGOs, women's groups, activists, education, international organizations)

vii) Can you give examples of successful initiatives or particular people promoting gender equality, women's rights and women's participation and leadership in your own community? How do you characterize success? (Prompt for any examples, exploring what the initiatives entail, who the key actors are, where they are, how they can be contacted). What doesn't work?

6. What are your practical recommendations to improve women's participation and leadership? Gender equality? Women's rights in your community?

7. Further comments invited from participants. 


\section{Appendix 5: Schedule of questions for focus group participants}

\section{Conceptual understandings of women's 'participation' and 'leadership'}

What does this mean to you?/What do you think of when you hear this?/Is this important to you? (Explore whether there is a difference between what this is thought to mean in theory, and whether participants perceive it to be different from their own experience).

What does it cover? What should it cover? What is important to you?

What does being a member of society/being a citizen mean to you? (Explore, for example, whether there is a greater focus on legal status, rights, moral framing, participation, identity, etc.).

How does this relate to womens' role in society? Women's participation and leadership ? Gender equality?

What does it mean to talk about women's leadership and participation in refugee populations? (Explore attitudes to participation and leadership for those with different legal/citizenship status e.g. refugees).

\section{Current situation:}

1. According to you, what are the current levels of women's participation in the public and private sphere? And similarly, for leadership?

2. What do you think about current levels of women's participation?

3. What do you think about current levels of women's leadership?

4. Explore this in different domains for both participation and leadership, e.g. education, employment, politics, culture.

5. In your view, who are the main actors in the domain of women's leadership and participation? How would you characterize the women who currently participate and lead in your community? What are the barriers to such participation and leadership/who gets excluded? Do you think there is enough focus on ordinary women? (Prompt for how this might vary by socio-economic class, religion, age, citizenship-status).

What does gender equality mean in practice?

1. What does gender equality mean to you? (Unpack this with the group, explore gender roles and expectations; explore if this is understood in terms of rights, responsibilities, other; what rights does it entail?).

2. What influences these perceptions?

3. Should these be challenged?

4. How should they be challenged?

5. What does gender equality mean to you on a personal level in terms of your own daily experiences? (Prompt participants for actual examples).

6. Do you think more should be done to promote gender equality? Why or why not?

Exploring possibilities for change:

1. What can be done that would lead to greater participation and leadership by women in society?

2. How and/or does this relate to gender equality? Women's rights?

3. Who are the actors bringing about change?

4. What in your view are the greatest challenges? (Prompt participants to explore e.g. people's opinions, practices, culture, tradition, institutions e.g. education, media, foreign intervention, conflict etc.).

5. What in your view are the possible opportunities that can lead to change? (e.g. could prompt discussion on ongoing revolutions and change in the Arab world, role of NGOs, women's groups, activists, education, international organizations). 
6. Are you aware of any initiatives or particular people promoting gender equality, women's rights and women's participation and leadership in your own community? (Prompt for any examples, exploring what the initiatives entail, who the key actors are, where they are, how they can be contacted).

\section{Appendix 6: Written consent form}

\section{Written Consent Form for Stakeholder interviews}

Title of Project: Women's Participation and Leadership in Jordan, Lebanon and Iraq: Moving from Individual to Collective Change

Dina Kiwan (Principal Investigator), May Farah (Co-investigator)

Department of Sociology, Anthropology and Media Studies,

American University of Beirut, Lebanon

Hello. My name is Dina Kiwan (May Farah/name of recruited research assistant/s). I am a professor in the Department of Sociology, Anthropology and Media Studies at AUB. I would like to invite you to participate in a research study about women's leadership and participation in Jordan, Lebanon and Northern Iraq. You have been invited to participate given your role in this field of work. The study aims to explore what factors play a role in maintaining gender inequality, women and men's perceptions and attitudes to women's participation and leadership in society, your reflections of barriers and facilitators to women's leadership and participation, and any examples you can give of successful strategies and initiatives.

Before we begin, I would like to take a few minutes to explain why I am inviting you to participate and what will be done with the information you provide. I will ask a number of questions and we will be having a discussion about your thoughts on these issues. Please stop me at any time if you have questions about the study.

I am doing this study as part of a research project at AUB. It is commissioned by Oxfam, a humanitarian organization which works with local communities in the region. I will be talking to both women and men in groups to learn about their experiences and attitudes to the issue of women's participation and leadership in their communities in Lebanon, Jordan and Northern Iraq. There will be up to 40 such groups in Lebanon in four different locations (Beirut, Mt Lebanon, Saida and Nabatieh), up to 20 groups in Jordan (in Amman and Zarqa), and 10 groups in Iraq, in Erbil. In addition, we will be talking to leaders and activists ('stakeholders') - both men and women in the three countries, with plans to talk to up to 40 in Lebanon, 15 in Jordan, and 10 in Iraq. We will be asking stakeholders what they perceive to be the barriers and facilitators to women's leadership and participation and for their examples of successful strategies and initiatives. This collected information will be used to write a report for Oxfam and will also be used in published academic articles as well as in academic presentations. Your individual privacy and confidentiality of the information you provide will be maintained in all published and written data analysis resulting from the study. If you consent to allowing me to quote from this interview, pseudonyms will be used in place of real names. Your name will not be mentioned in any quotes of things that you say, unless you specifically request this. The data collected for this project will only be shared by the research team, and will be kept securely at AUB. Research records will be monitored and may be audited without violating confidentiality.

Participation should take approximately 1 to 1.5 hours. Please understand your participation is entirely on a voluntary basis and you have the right to withdraw your consent or discontinue participation at any time without penalty or loss of benefits to which you are entitled, nor will it affect your relationship with AUB, AUBMC and Oxfam. Risks in taking part in this study are judged to be minimal, and these are further minimized by no reference to your name if you agree to quoting from what you say during this session. 
There are no direct benefits from participating in the study. However, it is hoped that this research project provides a safe and moderated opportunity to consider and discuss issues facing women's position and roles in society, and how this relates to women's leadership and participation. It is expected that Oxfam GB will use these research findings in its practical application of planned projects to support women's leadership and participation in the communities in Lebanon, Jordan and Iraq.

If at any time and for any reason, you would prefer not to answer any questions, please feel free not to respond to those questions. If at any time you would like to stop participating, please tell me. You can take a break, stop and continue at a later date, or stop altogether. You will not be penalized for deciding to stop participation at any time, and you do not need to give a reason for terminating your participation.

I would like to tape record this interview so as to make sure that I remember accurately all the information you provide. To secure the confidentiality of your responses, your name and other identifying information will never be attached to your answers (unless you specifically request that your responses be directed attributed to you by name). All codes and data are kept in a locked drawer and in a password-protected computer that is kept secure. Data access is limited to the Principal Investigator and researchers working directly on this project. All data will be destroyed responsibly after five years. Your privacy will be maintained in all published and written data resulting from this study. Your name or other identifying information will not be used in our reports or published papers, unless you wish to be named.

If you have any questions, you are free to ask them now. If you have questions, concerns or complaints about this research study later, you may contact me at:

Dina Kiwan,

Department of Sociology, Anthropology and Media Studies,

American University of Beirut,

Riad El-Solh,

Beirut, 11072020,

Lebanon .

Email: dk32@aub.edu.lb

Tel: $+96101350000 \times 3836$

If you are not satisfied with how this study is being conducted, or if you have any concerns, complaints, or general questions about research or your rights as a participant, please contact the AUB Social \& Behavioral Sciences Institutional Review Board (SBSIRB) at AUB:

American University of Beirut

PO BOX: 11-0236 F15

Riad El Solh, Beirut 11072020

Lebanon

Telephone: 009611 374374, ext: 5445

Fax: 0009611738025

E-mail: irb@aub.edu.lb 
In addition, Oxfam's Regional Gender Hub can be contacted at:

Regional Gender Justice Program Oxfam Great Britain, Mousalli Building Floors 1-4, Hamra Street, Beirut.

Are you interested in participating in this study?

\section{Consent to Record Interview}

(Question should be posed before any recording begins)

May I record this interview?

\section{Consent to Quote from Interview}

I may wish to quote from this interview either in the report, articles or presentations resulting from this work. A pseudonym will be used in order to protect your identity.

Do you allow me to quote from this interview?

\section{Consent to Use Name}

There may be reasons for which you prefer that your true name be used in presentations and articles related to this research.

Would you like your true name to be used in any oral presentations or written documents resulting from this research?

\section{Confirmation of Consent to Record Interview}

(Question will be posed once recording has begun)

May I record this interview?

I have read and understand the above information. I agree to participate in the research study.

Participation and recording:

Participant signature : Date:

Consent to use name:

Participant signature : Date: 


\title{
Appendix 7: Oral consent form
}

\section{Oral Consent Form for focus group participants}

\section{Title of Project: Women's Participation and Leadership in Jordan, Lebanon and Iraq: Moving from Individual to Collective Change}

\author{
Dina Kiwan (Principal Investigator), May Farah (Co-investigator) \\ Department of Sociology, Anthropology and Media Studies, \\ American University of Beirut, Lebanon
}

Hello. My name is Dina Kiwan (May Farah/name of recruited research assistant/s). I am a researcher in the Department of Sociology, Anthropology and Media Studies at AUB. I would like to invite you to participate in a research study about women's leadership and participation in Jordan, Lebanon and Northern Iraq. The study aims to explore what factors play a role in maintaining gender inequality, and also to explore women and men's perceptions and attitudes to women's participation and leadership in society.

Before we begin, I would like to take a few minutes to explain why I am inviting you to participate and what will be done with the information you provide. I will ask a number of questions and as a small group of between five to eight other women (insert men if male group), we will be having a discussion about your thoughts on these issues. Please stop me at any time if you have questions about the study.

I am doing this study as part of a research project at AUB. It is commissioned by Oxfam, a humanitarian organization which works with local communities in the region. I will be talking to both women and men in groups to learn about their experiences and attitudes to the issue of women's participation and leadership in their communities in Lebanon, Jordan and Northern Iraq. There will be up to 40 such groups in Lebanon in four different locations (Beirut, Mt Lebanon, Saida and Nabatieh), up to 20 groups in Jordan (in Amman and Zarqa), and 10 groups in Iraq, in Erbil. In addition, we will be talking to leaders and activists ('stakeholders') - both men and women in the three countries, with plans to talk to up to 40 in Lebanon, 15 in Jordan, and 10 in Iraq. We will be asking stakeholders what they perceive to be the barriers and facilitators to women's leadership and participation and for their examples of successful strategies and initiatives. This collected information will be used to write a report for Oxfam, and will also be used in published academic articles as well as in academic presentations. Your individual privacy and confidentiality of the information you provide will be maintained in all published and written data analysis resulting from the study. Please be aware however, that total confidentiality cannot be ensured as it also depends on individual members of the group. Your name will not be mentioned in any quotes of things that you say, and only if you give that permission. Pseudonyms will be used in place of real names. The data collected for this project will only be shared by the research team, and will be kept securely at AUB. Research records will be monitored and may be audited without violating confidentiality.

Participation should take approximately one hour. Refreshments will be provided. Please understand your participation is entirely on a voluntary basis and you have the right to withdraw your consent or discontinue participation at any time without penalty or loss of benefits to which you are entitled, nor will it affect your relationships with AUB, AUBMC and Oxfam. Risks in taking part in this study are judged to be minimal, and these are further minimized by no reference to your name if you agree to quoting from what you say during this session. There are no direct benefits from participating in the study. However, it is hoped that this research project provides a safe and moderated opportunity to consider and discuss issues facing women's position and roles in society, and how this relates to women's leadership and participation. It is expected that Oxfam GB will use these research findings in its practical application of planned projects to support women's leadership and participation in the communities in Lebanon, Jordan and Iraq. 
If at any time and for any reason, you would prefer not to answer any questions, please feel free not to respond to those questions. If at any time you would like to stop participating, please tell me. You can take a break, stop and continue at a later date, or stop altogether. You will not be penalized for deciding to stop participation at any time, and you do not need to give a reason for terminating your participation.

I would like to tape record this interview so as to make sure that I remember accurately all the information you provide. To secure the confidentiality of your responses, your name and other identifying information will never be attached to your answers. All codes and data are kept in a locked drawer and in a passwordprotected computer that is kept secure. Data access is limited to the Principal Investigator and researchers working directly on this project. All data will be destroyed responsibly after five years. Your privacy will be maintained in all published and written data resulting from this study. Your name or other identifying information will not be used in our reports or published papers.

If you have any questions, you are free to ask them now. If you have questions, concerns or complaints about this research study later, you may contact me at:

Dina Kiwan,

Department of Sociology, Anthropology and Media Studies,

American University of Beirut,

Riad El-Solh,

Beirut, 11072020,

Lebanon .

E-mail: $\underline{\text { dk32@aub.edu.lb }}$

Tel: $+96101350000 \times 3836$

If you are not satisfied with how this study is being conducted, or if you have any concerns, complaints, or general questions about research or your rights as a participant, please contact the AUB Social \& Behavioral Sciences Institutional Review Board (SBSIRB) at AUB:

American University of Beirut

PO BOX: 11-0236 F15

Riad El Solh, Beirut 11072020

Lebanon

Telephone: 009611374374 , ext: 5445

Fax: 0009611738025

E-mail: irb@aub.edu.lb

In addition, you can also contact Oxfam's Regional Gender Hub at:

Regional Gender Justice Program Oxfam Great Britain, Mousalli Building Floors 1-4, Hamra Street, Beirut.

Are you interested in participating in this study?

61 I P g e 


\section{Consent to Record Interview}

(Question should be posed before any recording begins)

May I record this interview?

\section{Consent to Quote from Interview}

I may wish to quote from this interview either in the report, articles or presentations resulting from this work. A pseudonym will be used in order to protect your identity.

Do you allow me to quote from this interview?

\section{Confirmation of Consent to Record Interview}

(Question will be posed once recording has begun)

May I record this interview?

You are not required to sign, but you will be given a copy of this consent form signed by the researcher. 


\section{Appendix 8: Tables of perceptions of obstacles to women's participation and leadership}

\section{Lebanon stakeholders}

\begin{tabular}{|c|c|}
\hline PERSONAL & SOCIETAL \\
\hline $\begin{array}{l}\text { Lack of knowledge of rights - men and women } \\
\text { Fear of change } \\
\text { Fear of family/societal criticism } \\
\text { Lack of male support/responsibility in the } \\
\text { household/too many roles/responsibilities }\end{array}$ & $\begin{array}{l}\text { Poverty, and associated pressures e.g. transport } \\
\text { costs } \\
\text { Political/security situation } \\
\text { Patriarchal perceptions } \\
\text { Perceived limitations with respect to gender roles; } \\
\text { politics as masculine } \\
\text { Family pressure; culture of shame } \\
\text { Sectarianism/no conception of citizenship, } \\
\text { democracy } \\
\text { Issues not recognized }\end{array}$ \\
\hline STRUCTURAL & STRATEGIC \\
\hline $\begin{array}{l}\text { Lack of institutional access/no quotas/political } \\
\text { parties not inclusive } \\
\text { Not a governmental priority } \\
\text { Lack of laws to protect women } \\
\text { Lack of access to justice (although access to courts) } \\
\text { 'Glass ceiling' } \\
\text { Civil society donors funding trying to set } \\
\text { agenda/not acting as partners }\end{array}$ & $\begin{array}{l}\text { Lack of solidarity between women/lack of women's } \\
\text { professional networks } \\
\text { Lack of coordination between groups/initiatives } \\
\text { Off-putting terminology (e.g. gender, CEDAW), } \\
\text { perception of Western agenda } \\
\text { Tensions between academic/practitioner agendas } \\
\text { Professional climates of harassment/bullying } \\
\text { International donors not knowing the issues } \\
\text { Human rights discourses used to sideline women's } \\
\text { rights discourses } \\
\text { Refugees protection beyond state protection/at } \\
\text { mercy of camp militia }\end{array}$ \\
\hline
\end{tabular}




\begin{tabular}{|c|c|}
\hline \multicolumn{2}{|c|}{ Obstacles perceived by Beirut focus groups } \\
\hline PERSONAL (FEMALE) & PERSONAL (MALE) \\
\hline $\begin{array}{l}\text { - Internalized responsibility/guilt to balance } \\
\text { multiple roles }\end{array}$ & - Women themselves do not push forward \\
\hline SOCIETAL (FEMALE) & SOCIETAL (MALE) \\
\hline $\begin{array}{l}\text { - } \quad \text { Limited mobility } \\
\text { - } \quad \text { Fear of sexual harassment } \\
\text { - } \quad \text { Misinterpretation of biology (e.g. of } \\
\text { - } \text { women's inherently emotional nature) } \\
\text { - } \text { Lebanon's both conservative and liberal } \\
\text { identity } \\
\text { - Religion/misinterpretation of religion } \\
\text { - Internalizing perception of inferiority } \\
\text { - Family }\end{array}$ & $\begin{array}{l}\text { - } \quad \text { Limited mobility } \\
\text { - } \text { Perception of need to protect women's } \\
\text { - } \text { Misinterpretation of Islam } \\
\text { - } \quad \text { Lack of education } \\
\text { - } \quad \text { Feminists (although some mentioned their } \\
\text { absence as negative) }\end{array}$ \\
\hline - $\quad$ STRUCTURAL (FEMALE) & - STRUCTURAL (MALE) \\
\hline $\begin{array}{l}\text { - Perception that women work under less } \\
\text { favourable conditions (especially migrant } \\
\text { women) } \\
\text { - Discrimination (including racism for } \\
\text { migrant and refugee women) } \\
\text { - } \quad \text { Risk of sexual harassment in workplace } \\
\text { Nepotism (women only leaders if they are } \\
\text { related to a male in power) }\end{array}$ & $\begin{array}{l}\text { - Sectarianism } \\
\text { - } \quad \text { Civil society's divisive nature }\end{array}$ \\
\hline STRATEGIC (FEMALE) & (STRATEGIC MALE) \\
\hline & $\begin{array}{l}\text { - Media's coverage of negative issues } \\
\text { - Objectification/commodification of women } \\
\text { in the media }\end{array}$ \\
\hline
\end{tabular}




\begin{tabular}{|c|c|}
\hline \multicolumn{2}{|c|}{ Obstacles perceived by Mt Lebanon focus groups } \\
\hline PERSONAL (FEMALE) & PERSONAL (MALE) \\
\hline $\begin{array}{l}\text { - Internalized responsibility/guilt to balance } \\
\text { multiple roles } \\
\text { - Men's attitudes or feelings of being } \\
\text { threatened by women earning } \\
\text { - Fear of loss of honour }\end{array}$ & $\begin{array}{l}\text { - Perception of women's } \\
\text { emotional/biological nature or } \\
\text { differentiating characteristics }\end{array}$ \\
\hline SOCIETAL (FEMALE) & SOCIETAL (MALE) \\
\hline $\begin{array}{l}\text { - } \text { Religion (specifically Islam) } \\
\text { - } \text { Misinterpretation of religion } \\
\text { - } \quad \text { Limited mobility } \\
\text { - } \quad \text { Customs/thinferiority complexes } \\
\text { - } \quad \text { Attitudes on women's education/marriage } \\
\text { - } \quad \text { Expectation to balance multiple roles } \\
\text { - } \quad \text { Violence - physical and verbal }\end{array}$ & 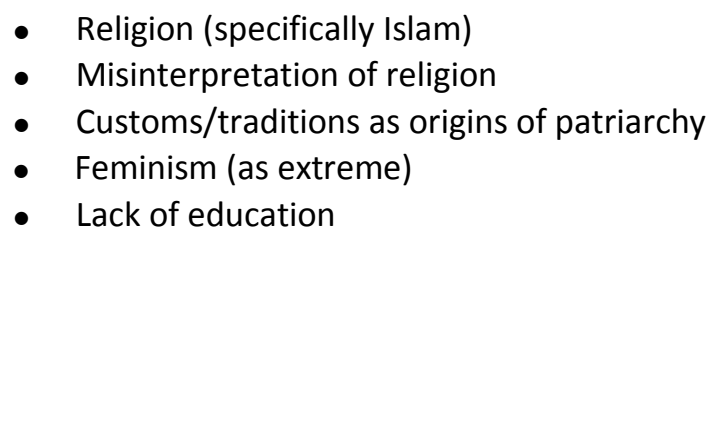 \\
\hline - STRUCTURAL (FEMALE) & - STRUCTURAL (MALE) \\
\hline - Sectarianism & \\
\hline STRATEGIC (FEMALE) & (STRATEGIC MALE) \\
\hline $\begin{array}{l}\text { - Objectification/commodification of women } \\
\text { in the media }\end{array}$ & $\begin{array}{l}\text { - Objectification/commodification of women } \\
\text { in the media } \\
\text { - Western rights discourse } \\
\text { - Politician's ownership and use of media }\end{array}$ \\
\hline
\end{tabular}




\begin{tabular}{|c|c|}
\hline \multicolumn{2}{|c|}{ Obstacles perceived by Saida focus groups } \\
\hline PERSONAL (FEMALE) & PERSONAL (MALE) \\
\hline $\begin{array}{l}\text { - Internalized responsibility/guilt to balance } \\
\text { multiple roles } \\
\text { - Husband and future husband's } \\
\text { expectations }\end{array}$ & $\begin{array}{l}\text { - Women themselves do not push forward } \\
\text { - Perception of women's } \\
\text { emotional/biological nature or } \\
\text { differentiating characteristics } \\
\text { - Men's fear of losing control }\end{array}$ \\
\hline SOCIETAL (FEMALE) & SOCIETAL (MALE) \\
\hline $\begin{array}{l}\text { - } \quad \text { Limited mobility } \\
\text { - } \text { role } \\
\text { - Interpretation of religion/Islam } \\
\text { - } \quad \text { Discrimination within law based on religion } \\
\text { - } \quad \text { Expectations tradion balance multiple roles } \\
\text { - } \quad \text { Lack of knowledge of gender/sexuality } \\
\text { - } \quad \text { Family violence }\end{array}$ & $\begin{array}{l}\text { - Interpretation of religion/Islam } \\
\text { - Perceptions of patriarchy } \\
\text { - } \text { Family pressures and perceptions } \\
\text { - Lack of awareness of the issues }\end{array}$ \\
\hline STRUCTURAL (FEMALE) & STRUCTURAL (MALE) \\
\hline $\begin{array}{l}\text { - Sectarianism } \\
\text { - Lack of faith in government institutions }\end{array}$ & - Lack of government support \\
\hline STRATEGIC (FEMALE) & (STRATEGIC MALE) \\
\hline $\begin{array}{l}\text { - NGOs/organizations don't pay attention to } \\
\text { the context/on-the-ground issues }\end{array}$ & $\begin{array}{l}\text { - NGOs/organizations don't pay attention to } \\
\text { the context/on-the-ground issues } \\
\text { - Objectification/commodification of women } \\
\text { in the media }\end{array}$ \\
\hline
\end{tabular}




\begin{tabular}{|c|c|}
\hline \multicolumn{2}{|c|}{ Obstacles perceived by Nabatieh focus groups } \\
\hline PERSONAL (FEMALE) & PERSONAL (MALE) \\
\hline $\begin{array}{l}\text { - Internalized responsibility/guilt to balance } \\
\text { multiple roles } \\
\text { - Husbands and male relatives' expectations }\end{array}$ & $\begin{array}{l}\text { - Women themselves do not push forward } \\
\text { - Men's discomfort taking orders from women }\end{array}$ \\
\hline SOCIETAL (FEMALE) & SOCIETAL (MALE) \\
\hline $\begin{array}{l}\text { - Limited mobility (criticism from community) } \\
\text { - Men's fear of losing control (e.g. economic } \\
\text { independence) } \\
\text { - Early marriages and pressure to have more } \\
\text { children } \\
\text { - Expectation to balance multiple roles }\end{array}$ & $\begin{array}{l}\text { - Religion } \\
\text { - Misinterpretation of religion (specifically Islam) } \\
\text { - Women influenced by Western paradigms } \\
\text { leading to conflict with men } \\
\text { - Lack of education } \\
\text { - Traditions/customs as origins of patriarchy }\end{array}$ \\
\hline STRUCTURAL (FEMALE) & STRUCTURAL (MALE) \\
\hline $\begin{array}{l}\text { - Economic exploitation } \\
\text { - Limited appropriate job opportunities } \\
\text { - Sectarianism }\end{array}$ & $\begin{array}{l}\text { - Civil society's divisive nature } \\
\text { - Corruption (specifically of organizations) } \\
\text { - Lack of government support }\end{array}$ \\
\hline STRATEGIC (FEMALE) & (STRATEGIC MALE) \\
\hline - Viewed as 'Western' when asking for rights & $\begin{array}{l}\text { - NGOs/organizations don't pay attention to the } \\
\text { context/on-the-ground issues } \\
\text { - Western rights discourse } \\
\text { - Media's exaggeration of issues }\end{array}$ \\
\hline
\end{tabular}




\begin{tabular}{|c|c|}
\hline PERSONAL & SOCIETAL \\
\hline $\begin{array}{l}\text { - Husbands control and monitor wives } \\
\text { - } \quad \text { Disincentive to work as husband controls } \\
\text { - Lomen's earned money } \\
\text { - Lack salaries for women } \\
\text { expectations }\end{array}$ & $\begin{array}{l}\text { - Family obligations and expectations } \\
\text { - Tribal mentality } \\
\text { - } \quad \text { Religious interpretations } \\
\text { - } \quad \text { Increased conservatism due to regional } \\
\text { - } \text { and Islamist movements } \\
\text { - } \text { Culture of shame } \\
\text { - Education } \\
\text { - } \text { Different understandings of what gender } \\
\text { equality, participation and leadership } \\
\text { mean }\end{array}$ \\
\hline STRUCTURAL & STRATEGIC \\
\hline $\begin{array}{l}\text { - } \quad \text { Patriarchy } \\
\text { - } \text { Lack of funding for women's rights and } \\
\text { - } \text { Quotas seen as a token and not } \\
\text { substantive } \\
\text { - } \quad \text { No concept of citizenship, regardless of } \\
\text { gender } \\
\text { - Tribal system institutionally embedded } \\
\text { - Seeming intention of government } \\
\text { bureaucracy to impede CSO work } \\
\text { - Lack of supporting services (such as day } \\
\text { care) }\end{array}$ & $\begin{array}{l}\text { - } \quad \text { Gender issues trivialized in media } \\
\text { - } \quad \text { Negative gendered media representations } \\
\text { - } \quad \text { Conditions set by international donors }\end{array}$ \\
\hline
\end{tabular}




\begin{tabular}{|c|c|}
\hline \multicolumn{2}{|c|}{ Obstacles perceived by Amman focus groups } \\
\hline PERSONAL (FEMALE) & PERSONAL (MALE) \\
\hline $\begin{array}{l}\text { - } \quad \text { Fear/lack of confidence } \\
\text { - } \quad \text { Perception of women's } \\
\text { emotional/biological nature or } \\
\text { differentiating characteristics } \\
\text { - Men's attitudes } \\
\text { - } \quad \text { Lack of awareness } \\
\text { - } \quad \text { Pressure of dual role in both the home and } \\
\text { work life }\end{array}$ & $\begin{array}{l}\text { - Perception of women's } \\
\text { emotional/biological nature or } \\
\text { differentiating characteristics }\end{array}$ \\
\hline SOCIETAL (FEMALE) & SOCIETAL (MALE) \\
\hline $\begin{array}{l}\text { - Objectification/commodification of women } \\
\text { - } \text { Perception that participation threatens } \\
\text { men } \\
\text { - } \text { Family pressures } \\
\text { - } \quad \text { Limited mobility } \\
\text { - } \quad \text { Costs of participation (e.g. transport, } \\
\text { childcare, etc.) } \\
\text { - } \quad \text { Culture of shame }\end{array}$ & $\begin{array}{ll}\text { - } & \text { Tribalism and customs } \\
\text { - } & \text { Threat/challenges to the household } \\
\text { - } & \text { Rural/urban divide in openness to change }\end{array}$ \\
\hline \multirow[t]{2}{*}{ STRUCTURAL (FEMALE) } & STRUCTURAL (MALE) \\
\hline & $\begin{array}{l}\text { - } \quad \text { Funding and bureaucracy within } \\
\text { organizations/initiatives }\end{array}$ \\
\hline STRATEGIC (FEMALE) & (STRATEGIC MALE) \\
\hline $\begin{array}{l}\text { - International organizations not fitting } \\
\text { within local context }\end{array}$ & - Gender mixing in work contexts \\
\hline
\end{tabular}




\begin{tabular}{|c|c|}
\hline \multicolumn{2}{|c|}{ Obstacles perceived by Zarqa focus groups } \\
\hline PERSONAL (FEMALE) & PERSONAL (MALE) \\
\hline $\begin{array}{l}\text { - Perception of women's } \\
\text { emotional/biological nature or } \\
\text { differentiating characteristics }\end{array}$ & $\begin{array}{l}\text { - Perception of women's } \\
\text { emotional/biological nature or } \\
\text { differentiating characteristics }\end{array}$ \\
\hline SOCIETAL (FEMALE) & SOCIETAL (MALE) \\
\hline 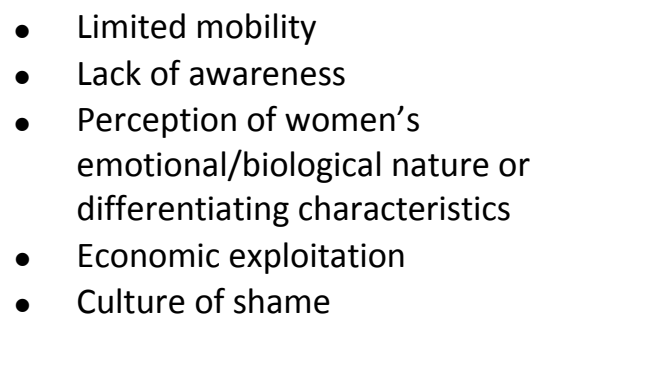 & $\begin{array}{l}\text { - Misinterpretation of religion } \\
\text { - } \quad \text { Tribal customs } \\
\text { Perception that certain practices are } \\
\text { honouring women (e.g. not having certain } \\
\text { types of jobs) } \\
\text { - Patriarchal society } \\
\text { - } \quad \text { Objear of sexual harassment }\end{array}$ \\
\hline STRUCTURAL (FEMALE) & STRUCTURAL (MALE) \\
\hline $\begin{array}{l}\text { - Lack of jobs in Zarqa } \\
\text { - Hiring discrimination (because may get } \\
\text { pregnant) }\end{array}$ & - Discriminatory laws (e.g. nationality law) \\
\hline \multirow[t]{2}{*}{ STRATEGIC (FEMALE) } & (STRATEGIC MALE) \\
\hline & $\begin{array}{l}\text { - NGOs/organizations don't pay attention to } \\
\text { the context/on-the-ground issues } \\
\text { - Western rights discourse }\end{array}$ \\
\hline
\end{tabular}




\section{PERSONAL}

- Women themselves (beliefs, attitudes, no desire to participate)

- Lack of awareness and knowledge

- Women feel their security is threatened outside the house

- Fear of opposing norms, culture, religion, tradition

\section{SOCIETAL}

- Political system (parties) and security situation

- Financial difficulties facing government and civil society

- Religion and conservative tribal culture (especially rural areas)

- Politics considered male arena

- Widespread gendered abuse

- Media representation and programming

- Fear of term 'gender'

- Women inferior, not taken seriously

- Early marriage, FGM, GBV, honour killings, shelters, hospitals

- No acceptance of LGBT people

\begin{tabular}{|c|c|}
\hline STRUCTURAL & STRATEGIC \\
\hline $\begin{array}{l}\text { - } \text { Lack of childcare } \\
\text { - } \quad \text { Laws not implemented } \\
\text { - } \quad \text { Curricula/schools } \\
\text { - } \text { Insufficient funding for projects } \\
\text { - } \quad \text { Men not willing to cede control } \\
\text { - } \quad \text { Male legacy of administration/ taking the } \\
\text { decisions }\end{array}$ & $\begin{array}{l}\text { - } \quad \text { Lack of solidarity between women } \\
\text { - } \quad \text { gack of coordination between } \\
\text { - } \quad \text { Fear of terms gender and CEDAW } \\
\text { - } \quad \text { Research inaccurate/insufficient } \\
\text { - } \quad \text { international donors not knowing the } \\
\text { - } \text { Funding restricted to refugees and } \\
\text { - } \quad \text { Gocurity/no government budget } \\
\text { - } \quad \text { awareness and training } \\
\text { - } \text { administration of university faculty and } \\
\text { Gender committees and councils not } \\
\text { effective }\end{array}$ \\
\hline
\end{tabular}


Obstacles perceived by Erbil focus groups

\begin{tabular}{|c|c|}
\hline PERSONAL (FEMALE) & PERSONAL (MALE) \\
\hline $\begin{array}{l}\text { - Husband } \\
\text { - } \text { Household and child-rearing } \\
\text { responsibilities } \\
\text { - } \text { desire, strength) } \\
\text { - Family honour and shame, threatened } \\
\text { - } \text { masculinities } \\
\text { - } \text { tradition } \\
\text { - } \quad \text { Lack of mobility for women support from other women }\end{array}$ & $\begin{array}{l}\text { - } \text { Family honour and shame } \\
\text { - Women's fear for their physical security } \\
\text { - } \text { Male harassment when out alone } \\
\text { - } \quad \text { Domestic violence } \\
\text { - Women decision makers self-serving and } \\
\text { - Wompetitive with other women } \\
\text { making }\end{array}$ \\
\hline SOCIETAL (FEMALE) & SOCIETAL (MALE) \\
\hline $\begin{array}{l}\text { - } \quad \text { Religion and clergy } \\
\text { - } \text { Political system (parties) and security } \\
\text { - } \quad \text { Conservative tribal culture (especially rural } \\
\text { areas). Shame } \\
\text { - Widespread gendered abuse } \\
\text { - } \quad \text { Negative perception among men and } \\
\text { - } \text { Momen } \\
\text { - } \quad \text { Fear of term 'gender' } \\
\text { - Women not taken seriously, seen as } \\
\text { inferior } \\
\text { Early marriage, FGM, GBV, honour killings, } \\
\text { shelters } \\
\text { Women sexualized/objectified } \\
\text { Women unable to access courts and police } \\
\text { stations }\end{array}$ & $\begin{array}{l}\text { - } \text { Tribal norms (contrasted with Christian } \\
\text { - } \quad \text { Religion and its } \\
\text { - } \quad \text { misinterpretation/clergymen } \\
\text { - } \quad \text { NGOs' ineffectiveness } \\
\text { - } \quad \text { Political parties not really believing in } \\
\text { gender equality, just 'window dressing' } \\
\text { - } \quad \text { Culture of shame } \\
\text { - } \quad \text { Somen seen as body, objectified } \\
\text { - } \quad \text { Education }\end{array}$ \\
\hline STRUCTURAL (FEMALE) & STRUCTURAL (MALE) \\
\hline $\begin{array}{l}\text { - } \quad \text { Laws not implemented } \\
\text { - } \quad \text { Curricula/schools } \\
\text { - } \quad \text { Shari'a-based law for all } \\
\text { - } \quad \text { Laws restrict women's mobility } \\
\text { - } \quad \text { Men outnumber women in authority and } \\
\text { decision making positions }\end{array}$ & $\begin{array}{l}\text { - Laws insufficient/not implemented to } \\
\text { protect women } \\
\text { - Women sexually exploited by authorities } \\
\text { - } \quad \text { Authorities have no gender awareness }\end{array}$ \\
\hline
\end{tabular}


- Women can only succeed with party support

- Quality of women assigned by quota

- Women's lack of participation in electoral process

- Lack of coordination between donor agencies and local NGOs/distance from society
- Constitution of equality not implemented

- Void between government institutions and people

- Shelters and legal aid limited/abuse in shelters

- $\quad$ CSO not effective; only working for money

- CSOs need ruling party support

- $\quad$ NGOs not spending effectively 
This paper was written by Dina Kiwan, May Farah, Rawan Annan and Heather Jaber, American University of Beirut, Beirut, Lebanon. It is part of a series of reports written to inform public debate on development and humanitarian policy issues.

The text may be used free of charge for the purposes of advocacy, campaigning, education, and research, provided that the source is acknowledged in full. The copyright holder requests that all such use be registered with them for impact assessment purposes. For copying in any other circumstances, or for re-use in other publications, or for translation or adaptation, permission must be secured and a fee may be charged. Email policyandpractice@oxfam.org.uk

For further information on the issues raised in this paper please email Dr Abigael Badoumas at ABaldoumas@oxfam.org.uk or go to www.oxfam.org

The information in this publication is correct at the time of going to press.

Published by Oxfam GB under ISBN 978-0-85598-691-9 in April 2016

Oxfam GB, Oxfam House, John Smith Drive, Cowley, Oxford, OX4 2JY, UK

Oxfam GB is a registered charity in England and Wales (no 202918) and Scotland (SC039042)

Oxfam GB is a member of Oxfam International

This report has been developed with the assistance of Oxfam in order to share research results and to contribute to debate on development and humanitarian policy and practice. The content and views expressed in this report are the responsibility of the author and do not necessarily represent the views of Oxfam.
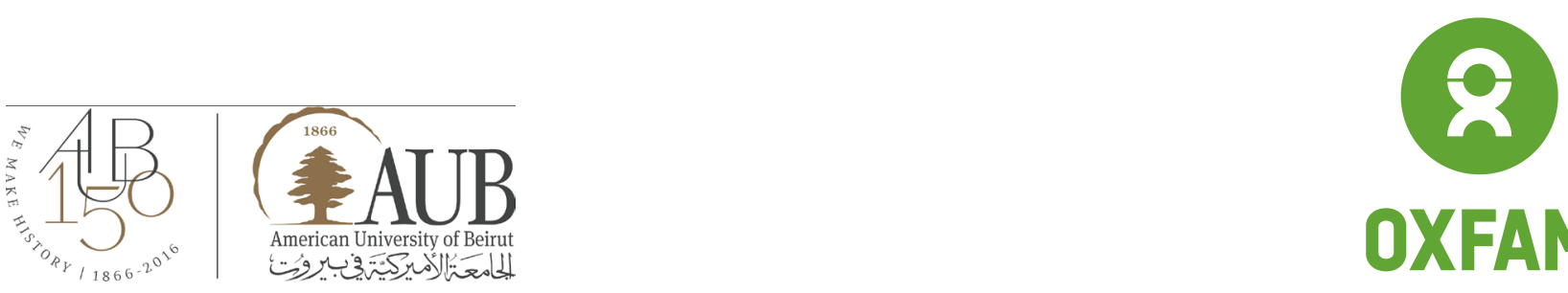